\title{
Farmers' Response to COVID-19 Disruptions in the Food Systems in Ghana: The case of cropland allocation decision
}

\author{
Edward Martey ${ }^{1 *}$, Peter Goldsmith ${ }^{2}$ and Prince M. Etwire ${ }^{1}$ \\ ${ }^{1}$ Socio-economic Section, CSIR-Savanna Agricultural Research Institute, P.O. Box TL 52, Tamale, Ghana \\ ${ }^{2}$ University of Illinois at Urbana-Champaign, 414 Mumford Hall, 1301 W Gregory Drive, Urbana, IL, USA \\ ${ }^{*}$ Corresponding author. \\ E-mail address: eddiemartey@gmail.com/martey2@illinois.edu (E. Martey).
}

\section{Authors profile}

Edward Martey (Email: eddiemartey@gmail.com; ORCID ID: 0000-0002-6933-3685) is an Agricultural and Applied Economist at the CSIR-Savanna Agricultural Research Institute and a visiting scholar at the University of Illinois at Urbana-Champaign. He received his BSc and MPhil (Agricultural Economics) and PhD (Agricultural and Applied Economics) degrees from the University of Ghana and University of Illinois at Urbana-Champaign, respectively. He is currently the Head of the Socio-economic Section of CSIR-SARI. His key research interests are in the areas of management of innovation platforms, farming systems research, agricultural commercialization, gender, value-chain development, and impact evaluation.

Dr Peter Goldsmith (Email: pgoldsmi@illinois.edu) is the Professor and Director, Food and Agribusiness Management Program, Department of Agricultural and Consumer Economics at the University of Illinois at UrbanaChampaign. Dr Goldsmith graduated in 1995 from the Ohio State University with a Ph.D. in Agricultural Economics. From 1995-1999 he worked as an Assistant Professor, McGill University in Montreal and is currently a Professor of Agribusiness Management in the Department of Agricultural and Consumer Economics, University of Illinois. In addition to his Ph.D., Dr Goldsmith has received an MBA in Finance, and undergraduate degrees in Dairy Science and Political Science. He is a leading scholar within the field of Agribusiness Management and is a Fellow of the International Food and Agribusiness Management Association. In addition to teaching Food Marketing, Dr Goldsmith developed the world's first course on agri-food supply chain management and blockchain applications. His research interest is global agro-industrial marketing and strategy specifically looking at intellectual property management, agricultural development, biotechnology, and supply chain management within soybean-livestock energy value chains. Dr Goldsmith, having worked extensively in Mato Grosso, Brazil and Argentina, is one of the world's leading soybean economists with unique expertise in low latitude soybean production and agro-industrial development. Dr Goldsmith serves as the Director and Principal Investigator of USAID's Feed the Future Lab for Soybean Value Chain Research, a $\$ 20 \mathrm{~m}$ research enterprise that operates in 27 countries.

Prince M. Etwire (Email: etwiremaxwellprince@gmail.com; ORCID ID: 0000-0002-6533-2538) is a Research Scientist (Agricultural Economist) at the CSIR-Savanna Agricultural Research Institute, Tamale, Ghana where he has been a faculty member of the Socio-economic Section since 2009. He received his BSc (Agricultural Technology), MPhil (Agricultural Economics) and PhD (Economics) degrees from the University for Development Studies, University of Ghana and University of Otago, respectively. His research interests are in the areas of modelling climate change adaptation, productivity studies, general microeconomic modelling, monitoring and evaluation of agricultural projects and building of organizational capacity. 


\begin{abstract}
The COVID-19 pandemic is a global health issue with disruption effects in the agricultural food systems especially in Sub-Saharan Africa (SSA) where most of the population is engaged in the agricultural sector. While prices of food commodities continue to increase, farmers are likely to be food insecure or market-oriented by allocating land resources between commercial and staple crops. This study provides new evidence on the determining factors of cropland allocation decisions within the context of the COVID-19 pandemic. The study employs the probit and seemingly unrelated regression (SUR) models on 309 farm households. The results reveal that socio-economic, production, institutional, and political factors significantly influence the choice of cropland allocation decisions and the size of cropland allocated to legumes and cereals. Beyond these factors, we find that COVID-19 education increases land area allocated to staples while farmers' perception that COVID-19 will impact negatively on agricultural production leads to an increase in the area under commercial crop (soybean) production. The result suggests that promoting farmer education on the disruptive effects of the COVID-19 pandemic and understanding farmer perceptions of the disruptive effects of the COVID-19 will guide future adaptation and mitigation strategies as well as determining the "best" possible cropland allocation decision.
\end{abstract}

Keywords: COVID-19 pandemic; crop land allocation; commercial and staple crops; seemingly unrelated regression 


\section{Introduction}

The novel COVID-19 pandemic is a global emergency affecting all countries with older people, poor households, the undernourished, and those who live in remote areas being the most affected (Afridi et al., 2020). This pandemic has resulted in a huge economic shock leading to disruption in the agricultural sector and the food supply chains. The pandemic has resulted in several deaths leading to loss of human capital and labor (Abate et al., 2020; Laborde et al., 2020). In response to the COVID-19 pandemic, the World Health Organization (WHO) encouraged member countries to implement strategies well suited for each country such as social distancing, washing of hands under running water, covering of mouth and nose with a face mask, covering mouth when sneezing and coughing, and constantly disinfecting surfaces highly exposed to contamination. Due to the spread of the infection, countries have resorted to partial and total lockdown to contain the spread of the virus. However, these strategies have both positive and negative consequences on the livelihoods of people. The question that lingers on the mind of several leaders is a trade-off between health and the economy.

The agricultural production, distribution, and marketing sectors are expected to be disrupted (Afridi et al., 2020; Laborde et al., 2020). For, example the non-availability of migrant labor will interrupt planting and harvesting activities in the immediate future. Production of food crops is expected to be affected negatively, therefore limiting the food systems with devastating impacts on food security (Laborde et al., 2020). The reduction in food supply to the urban centers may result in price hikes. Transportation of food to the urban centers is affected due to the disruptions in the transportation sector and large agribusiness input firms may partially withdraw leading to high input prices (Afridi et al., 2020). The partial lockdown imposed in some EU countries, the 
United States and Asia are likely to impact negatively on the transfer of remittances to rural households. Similarly, the partial lockdown in the two major regions of Ghana (Greater Accra and Ashanti Regions) is likely to impact on internal remittances to rural households and may cause trade disruptions.

Most of the food production occurs in northern Ghana while the southern part of Ghana (Greater Accra and Ashanti regions) is recognized as the consumption centers. A previous study by Martey et al. (2019) indicates that markets in Ashanti and Northern regions serve as lead production and demand markets, respectively. Any trade disruptions (for example, reduction in the supply of agricultural inputs and volume of trade) between these markets due to external shock are likely to disrupt the agricultural production systems. For example, a reduction in the number of buyers of commercial crops (legumes) due to the partial lockdown may result in a deflationary price effect in the production zones. Alternatively, high demand in the consumption zones of the country will result in an inflationary price effect. Recently published report by the Ghana Statistical Service (GSS) indicates that inflation currently stands at $11.3 \%$ in May while inflation of $10.6 \%$ was observed in April. These price hikes have been attributed to the partial lock-down which spanned for three weeks. However, an increase in food prices have contributed largely to the current inflation figures. Based on regional disaggregation, Greater Accra recorded the highest inflation $(13.3 \%)$ relative to the other regions (3.1\%-9\%). Food inflation contributes close to $60 \%$ of the May inflation figure (Ghana Statistical Service ${ }^{1}$, 2020).

${ }^{1}$ https://statsghana.gov.gh/gssmain/fileUpload/Price\%20Indices/Bulletin_\%20CPI\%20May\%202020.pdf. 
The rural agricultural sector may be affected to the extent that farmers may strategize by reallocating land resource between staples (cereals - maize and rice) and commercial crops (legumes - soybean and groundnut) in response to high food prices. Several studies have shown that smallholder farmers are more likely to use strategies that allow them to mitigate the effect of any disruptive agricultural phenomenon (Kom et al., 2020; Martey et al. 2020; Tambo 2016). For example, Kom et al. (2020) find that farmers in Vhembe District of South Africa respond to climate shock by adopting drought-tolerant seeds, shorter cycle crops, diversification of crops, changing planting dates, small-scale irrigation, migrating to urban areas, and involvement in petty trading. A study by Dedewrwaerdere \& Hannachi (2019) show that farmers' decision to shift to the marketoriented production systems is strongly influenced by changes in the norms of disease management, influential factors (government technicians/head of the village), and the taste and preferences of urban inhabitants. Martey et al. (2020) find that perceptions of climate variability and shocks have a heterogeneous effect on the adoption of multiple integrated soil fertility management practices (ISFM) practices. Farmers exposed to precipitation shocks are more likely to complement mulch with residue as an adaptive response to evapotranspiration while substitute mulch with mineral fertilizer. The results highlight the risk-averse decisions and mitigation strategies employed by farmers. Mitter et al. (2015) find that farmers in developing countries diversify their crop portfolios as a mitigation strategy against climate variability but Birthal et al. (2015), Arouri et al. (2014), and Stuart et al. (2014) indicate that the intensity of crop diversification differ from farmer to farmer due to the differences in the production capacity and perception of climate variability. 
While food price hike poses a serious threat to household food security, farmers are likely to benefit from the situation by becoming more market-oriented or self-sufficient in food. Farmers may respond to the price hike by reallocating land resources between commercial and staple crops. Therefore, the study hypothesizes that farmers respond positively to the price hike due to the COVID-19 pandemic by becoming more market-oriented (increasing area under commercial crops).

Several studies have highlighted the factors influencing cropland allocation decisions in Asia and SSA. Nguyen et al. (2017) extended the sustainable livelihoods framework to examine the factors affecting farmers' land-use choices and crop diversification in Vietnam and Thailand. In their framework, they showed that land is the major factor of crop production thus farmers' decision to cultivate annual or perennial crops is based on their inadequate ex-ante risk management and expost shock coping ability. The results of the analysis show that factors that determine crop diversification include farmland size, the share of irrigated and owned land, distance from homestead to the field, education, age, number of tractor and motorbikes, financial capital, access to credit, membership in social and political organizations, and experience of weather shock. Porgo et al. (2018) find that in Burkina Faso, credit constraint reduces farm households' allocation of land to maize and cotton production but rather increase land allocated to sorghum and millet. According to the study, the credit scheme favors cotton production relative to other crops thus influencing farmers' decision to allocate more land to cotton. Secondly, limited access to fertilizer tends to reduce land allocation to maize and cotton which requires more fertilizers than sorghum and millet. Kokoye et al. (2013) find that Benin is a net importer of food due to low agricultural production. In view of this, the government prioritized crop land management to reduce risk, 
achieve farm level objectives, and economic viability with subsequent improvement in food security. At the farmer level, land allocated to cereals and legumes is mainly determined by the location of the farmer, sex, off-farm income activities, group membership, farming experience, household size, the number of household's members working in agriculture, the agricultural wage labor used, the household's capital, and access to credit. In estimating the determinants of farmlevel decisions on cereal productions in Tanzania, Msongaleli et al. (2015) find that age of the household head, farming experience, having plots on particular soil types and access to weather information significantly influence choices of cereal crops among sorghum, pearl millet, and maize. Some of the studies reviewed provide limited evidence on how external health shocks can influence cropland allocation decisions for cereals and legumes within a developing context. The novel COVID-19 pandemic presents a unique case to ascertain the effect of health shocks on cropland allocation decisions.

In this study, we test the following hypotheses: (a) farmers are not aware of the disruptive effect of COVID-19 pandemic on agriculture; (b) land allocation decision between commercial (legumes) and staple (cereals) crops is not correlated to socio-economic, production, institutional, political, and external shock factors (c) farmers' do not respond to the COVID-19 pandemic disruptions by changing their current cropping patterns. Awareness of the COVID-19 pandemic is expected to influence farmers' input and crop choice (staple versus commercial), agricultural practices, and output market decisions. The study provides the basis for gauging the reality of the disruption of the food systems in Ghana given the absence of readily available data on the impact of COVID-19. The findings of the study contribute to building a strong local market and scaling up local value chains and contributing to generating country-specific solutions for local ownership. 
This study makes two main contributions to agricultural land use resource literature. First, it explores the level of farmers' awareness regarding the disruptive effect of COVID-19 on agricultural production. We find that a relatively high number of farmers are aware of the COVID19 pandemic but have limited information on the effect on agriculture as well as the preventive measures to contain the spread. Second, the paper extends the literature by assessing the correlation between COVID-19 and cropland use for staple and commercial crops. The results indicate that COVID-19 education increases land area allocated to staple production relative to commercial crop production while farmers' perception that COVID-19 will impact negatively (disruptions in the factor input market, food system, and transportation sector) on agricultural production leads to an increase in area under commercial production.

The rest of the paper is structured as follows: section 2 presents the rationale for legume and cereal production followed by the conceptual and theoretical framework and empirical strategy in section 3; in section 4, the sampling, data and summary statistics are presented while section 5 discusses the empirical results; concluding remarks and policy recommendations are provided in section 6.

\section{Rationale for commercial (legume) and staple (cereal) crop production within a developing context}

Production of commercial (such as legumes) and staple (such as cereals) crops by smallholder farmers are generally motivated by several factors. The primary rationale regarding smallholder farmers' intercropping behavior of cereals with legumes is for soil conservation and improvement of soil fertility, profit maximization, risk minimization, and weeds and pest control. This is important especially within a developing context like sub-Saharan Africa (SSA) where there are 
erratic rainfall and low input use. Farm households cultivate staples (cereals) for storage or consumed on-farm or sold to various market outlets. Staple foods require better coordination strategies between farmers and agro-processors to enhance the shelf-life. However, investment in staple food is constrained by the perception of low investment and higher risks for farmers and private agribusiness firms (Elbehri et al., 2013). The demand drivers for staple crops are domestic and spatially vary from local to regional in scope. The challenge with staple crops enterprise is the fact that they consist of a large and highly heterogeneous number of small-scale producers, where women are often important players in production, trading, and small-scale agro-processing (Elbehri et al., 2013).

Commercial crops such as legumes are mainly cultivated as a cash crop among smallholder farmers. Cultivation of commercial crop is a conscious effort based on individual and household aspirations. Farmers perceive the cultivation of commercial crops as a way of integrating into the market to hedge against external and uncontrollable changes (Finnis, 2006). For example, legumes are a major source of feed for livestock and a valuable complement to primarily carbohydratebased diet for humans given that they have high protein and micronutrients (Messina, 1999; Muoni et al., 2019; Ojiewo et al., 2015).

Beyond these benefits, legumes provide a range of biophysical benefits such as yield improvement through biological nitrogen fixation (BNF), soil fertility enhancement, and erosion control (Bationo et al., 2011; FAO, 2016; Thierfelder et al., 2012). The crop can generally be stored for a long period of time relative to root and tuber crops which are highly perishable. The low perishability of legumes enhances its commercialization between harvest thus reducing the risk of 
households becoming cash trapped (Chivenge et al. 2015; FAO, 2016). Due to the nitrogen fixation of legumes, they are intercropped with cereals especially maize, and rotated with other staple crops to increase crop yields while maintaining the quality of the soil (Odendo et al., 2011). According to Hassen et al. (2017) legumes may be intercropped with staple food crops as hedgerows along contour lines or along the field edges in smallholder farms.

Despite the numerous economic benefits of legumes-cereals intercropping, relatively new commercial leguminous crops like soybean require "high fixed-costs related to learning new production practices and input utilization methods, and high capital investments in mechanization and market linkages" are likely to reduce the adoption of soybean (Tamimie \& Goldsmith, 2019). Similarly, smaller farm households may not find soybean profitable if they are unable to spread their fixed costs over larger areas of land and attract buyers who will provide a competitive price for the grain (Tamimie \& Goldsmith, 2019).

Some studies have shown that the use of legumes in smallholder farms is influenced by socioeconomic factors such as gender, income, limited and uncertain market access, limited access to improved varieties, and lack of reliable supply of quality seed (Bezner Kerr et al., 2007; Mpepereki et al., 2000; Shelton et al., 2015; Waldman et al., 2016). In addition, agronomic factors such as relative competition between maize and the different legume crops when intercropped and farmers' perceptions of legume attributes influence the adoption of legumes (Waldman et al., 2016). The findings from the study by Waldman et al. (2016) show that farmers perceive nutrition as the most frequently mentioned legume attribute, followed by good marketability, taste, soil fertility, and yield/adaptability. 
The relationship between rural economies and the urban areas influences the choice of crops cultivated in rural areas. For example, Martey et al. (2020) find that soybean production in Northern Ghana is a response to high demand in the consumption areas of Ghana. In Kenya, Olwande et al. (2015) show that some farmers buy staple food crops from income generated through the cultivation and sale of cash crops. The market demand thus influenced the crop options to grow which subsequently influence the choice of inputs and varieties of crops to grow. In the Democratic Republic of Congo (DRC), lack of access to market and transportation services limits the crop options thus the focus on subsistence cultivation of cassava, yams, maize, and rice (Muoni et al., 2019). Farmers respond to higher domestic food prices by shifting land allocation decisions between crops. However, the ability of smallholder farmers to benefit from higher domestic prices is constrained by factors such as incidence of drought, higher input prices (especially fertilizer), and the timing of the price increase relative to their crop production cycle (Eldukherv et al., 2010).

\section{Conceptual, theoretical framework and empirical strategy}

\subsection{Conceptual framework}

Figure 1 shows the conceptual framework of the study. Agricultural land allocation is a rational decision-making process among smallholder farmers which has long-term effect on agricultural development and poverty reduction (Jayne et al., 2014). Farm households derive their main source of livelihood from agricultural production with land playing a critical role in the production

process. A household may allocate land among different crops with the expectation of achieving food security given that land is fixed. However, the objective of the farm household determines the extent to which agricultural land is distributed among crops. A farm household that cares more about food security will allocate more land to food crops such as cereals (maize and rice) while 
those that care more about income are likely to allocate more land to commercial crops such as legumes (soybean and groundnut). Nonetheless, some households may allocate land among different crops as a risk-reducing strategy with the ultimate objective of enhancing the welfare outcome of household members (Kruseman et al., 1996).

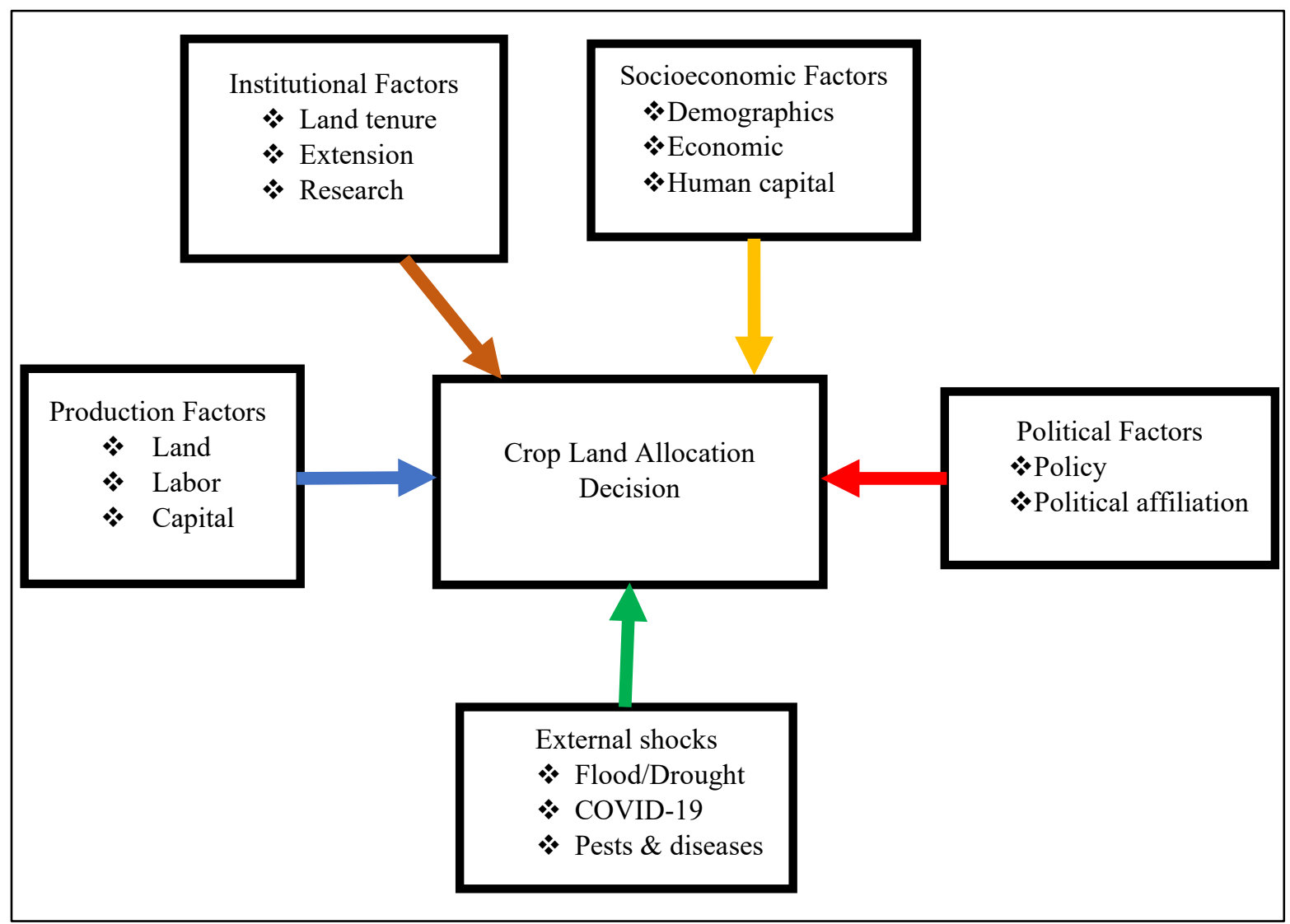

Fig. 1. Conceptual framework (Authors' construct)

Understanding land allocation decisions are critical for formulating evidenced-based agricultural policies since land is a fundamental input for production, especially among smallholder farmers. This study hypothesizes that land allocation decision is influenced by variables such as institutional, political, socio-economic, and production factors and external shocks (Kokoye et al., 2013). Production factors include land, management, capital, and labor. These factors are assumed 
to be used in equal proportion across the same crop category. Farmers will allocate more land to the crop category that maximizes profit/utility. Political factors include policies, political capital, and relationship with political figures. For example, policies that favour cereal production will witness a higher response by farm households by allocating more land to cereal production. Similarly, farmers who are related to political figures are more likely to benefit from agricultural development projects that promote specific crops. Socio-economic factors such as sex, education, age, total dependents, etc. are likely to influence land allocation among different crop types. ${ }^{2}$

Institutional factors such as land tenure system and access to extension and research have a direct effect on food security and livelihood activities and strategies through land resource allocation (Quan, 1998). Finally, the land allocation decision is expected to be influenced by external shocks such as geo-climatic, pests and diseases, and pandemics such as the novel Coronavirus, COVID19. The anticipated impacts of COVID-19 on trade and output prices can determine the allocation of land for agricultural production. Farmers are likely to allocate more land for legumes when the future price of legume is expected to be relatively higher than cereals due to the COVID-19 pandemic. Partial lockdowns and restrictions in the movement of goods and services disrupt food and input distribution systems. Disruption of trading during the lockdowns and other restrictions can lead to a decline in the selling price of food commodities thus influencing land allocation decisions of the affected crop types. We hypothesize that farmers will respond more favorably towards a crop category if the COVID-19 pandemic leads to market opportunities such as increase in output price, decrease in input price, and high demand.

\footnotetext{
${ }^{2}$ The utility that farmers obtain from different crops is likely to, for example, differ by age and educational status and therefore influence land allocation decisions.
} 


\subsection{Theoretical framework}

A household cropland allocation between multiple crops hinges on the theory of profit maximization. Following from the Neo-classical theory of rationality, farmers are considered rational as they seek to maximize net revenue subject to their budget and land constraints. According to Blaug (1992) "Rationality is a choice in harmony with a preferential arrangement that is complete and transitive, under conditions of perfect and cost-free awareness; where uncertainty of future results occurs, the rationality means maximizing expected utility, which is a utility multiplied by the probability of the occurrence of a given outcome."

Assuming an $i t h$ farmer allocating land among $m$ crops grown separately, then the land utilization choice is limited by the total available land specified as:

$$
\sum_{i=1}^{m} z_{i j}=\bar{Z}
$$

where $Z_{i j}$ is the total available acres that the $i t h$ farmer allocates to the $j$ th crop and $\bar{Z}$ is the total land endowment possessed by the individual farmer. Following the conceptual framework, the land allocation decision is influenced by socio-economic, institutional, political, production, and external shocks. The cost of production is assumed to be different across the $m$ crops given that farmers produce the crop independently. The cost for the $i t h$ farmer is given as:

$$
\vartheta_{i}=\sum_{j=1}^{m} w_{i j} z_{i j}
$$


where $w_{i j}$ is the constant per acre cost for the $j$ th crop. Given that farm holding for the various crops are not homogenous, the cost per acre is expected to be different for different farms. Similarly, the total revenue from the $j$ th crop is measured as a product of the price $\left(p_{i j}\right)$ received for the $j t h$ crop and output $\left(q_{i j}\right)$, expressed as:

$$
\varphi_{i}=\sum_{j=1}^{m}\left(p_{i j} q_{i j}\right) z_{i j}
$$

The total expected net revenue $\left(\pi_{i}\right)$ from $m$ crops is expressed as the difference between expected revenue (3) and costs (2), and may be expressed as a linear function of farmer acreages:

$$
\pi_{i}=\sum_{j=1}^{m} c_{i j} z_{i j}
$$

where $c_{i j}=p_{i j} q_{i j}-w_{i j}$ is the farmer expected per acre return from the $j t h$ crop. A farmer will maximize his/her profit by allocating land among $\mathrm{m}$ crops subject to the constraint (1).

$$
\max _{z_{i j}} \sum_{j=1}^{m} c_{i j} z_{i j} \text { s.t. } \sum_{i=1}^{m} Z_{i j}=\bar{Z}
$$

The profit function is assumed to be linearly homogenous and convex in $p_{i j}$ and $w_{i j}$, increasing in $p_{i j}$, decreasing in $w_{i j}$ and increasing and concave in $z_{i j}$. The first order conditions for profit maximization suggests that the marginal profit with respect to land allocation should be equal across all crops:

$$
\frac{\partial \pi(p, w, z)}{\partial z_{i}}=\cdots=\frac{\partial \pi(p, w, z)}{\partial z_{j}} \quad i, j=1, \ldots, m
$$


Following from the first order conditions, the optimal land allocation decision is a function of all expected output prices, input prices, and the fixed quantity of available land specified as:

$$
z_{i}^{*}=z_{i}(p, w, \bar{z}) \quad i=1, \ldots m
$$

According to Shumway et al. (1984), the optimal land allocation decision holds under the condition of jointness ${ }^{3}$ in production input technology and non-jointness through the allocation of fixed land as in our case. The optimal land allocation decision is directly proportional to the output price. An individual farmer will allocate more land to the crop with a high expected output price. The relationship between the optimal land allocation for crop $i$ and the input price of crop $j$ depends on the nature of the jointness of production. Following the argument of Oczkowski \& Bandara, (2013), "cross-price complementarity arises in the jointness case given that the increased use of one input tends to increase the marginal productivity of other inputs." Given that maize and soybean are jointly produced, if the farmer increases the production of soybean then the possibility of increasing maize production is high since the maize can benefit from the nitrogen fixation by the soybean.

\subsection{Empirical model}

Farm households allocate their available cropland to four major crops - maize, soybean, rice, and maize, therefore the probability of allocating a specific field to a crop may be correlated with the

\footnotetext{
${ }^{3}$ Jointness in production comes from either technical interdependencies or the presence of "non-allocatable" inputs that cannot be separately managed between products (see Romstad et al., 2000, p.15 and Nilsson, 2004, pp. 31-34).

Joint provision implies a technical interdependency in that the supply of one output (over some range) simultaneously affects the output of the second output.
} 
land allocated to other crops. The decision to allocate land to a specific crop is determined by exogenous factors that might be the same or differ among crops. Modeling of land allocation decision requires a model that accounts for the correlation of the error terms among the set of equations. The crops were grouped into two categories: (1) cereals (maize and rice) and (2) legumes (soybean and groundnut) given that not all households grow the same crop types. The study assumes that technology, inputs, output prices, and time allocation are homogeneous with crop categories.

Land allocation decision is expected to be influenced by factors such as socio-economic $(X)$, production $(R)$, political $(M)$, institutional $(I)$, and external shock $(E)$ (Fig. 1). Following the specification of Zellner (1962) and Kokoye et al. (2013), the empirical model is specified as follows:

$$
\left\{\begin{array}{l}
y_{i 1}=\gamma_{1} X_{i 1}+\beta_{1} R_{i 1}+\alpha_{1} M_{i 1}+\theta_{1} I_{i 1}+\delta_{1} E_{i 1}+e_{i 1} \\
y_{i 2}=\gamma_{2} X_{i 2}+\beta_{2} R_{i 2}+\alpha_{2} M_{i 2}+\theta_{2} I_{i 2}+\delta_{2} E_{i 2}+e_{i 2}
\end{array}\right.
$$

where $\gamma_{m}, \beta_{m}, \alpha_{m}, \theta_{m}$, and $\delta_{m}$ are the parameters to be estimated; $e_{i m}$ are the error terms. The parameters are estimated using the Ordinary Least Square (OLS) method through a "Seemingly Unrelated Regression" (SUR).

\section{Sampling, data and summary statistics}

\subsection{Sampling and data}

Figure 2 shows the Northern Region of Ghana where the study was carried out. The region used to have 26 districts with a land size of 70,384 square kilometers. In 2019, two new administrative 
regions (i.e. North East and Savannah) were carved out of the Northern Region bringing the total number to three. The region shares boundaries with the Upper East and the Upper West regions to the north, the Brong-Ahafo and Volta regions, to the south, and Togo to the east. Generally, the climate of the region is relatively dry, with a single rainy season that begins in May and ends in October with an average annual rainfall of 750 to $1,050 \mathrm{~mm}$, while the dry season, with temperatures of up to 38 degrees, occurs between November and April. The dominant crops cultivated include maize, yam, millet, sorghum, rice, groundnuts, soybean, and cowpea.

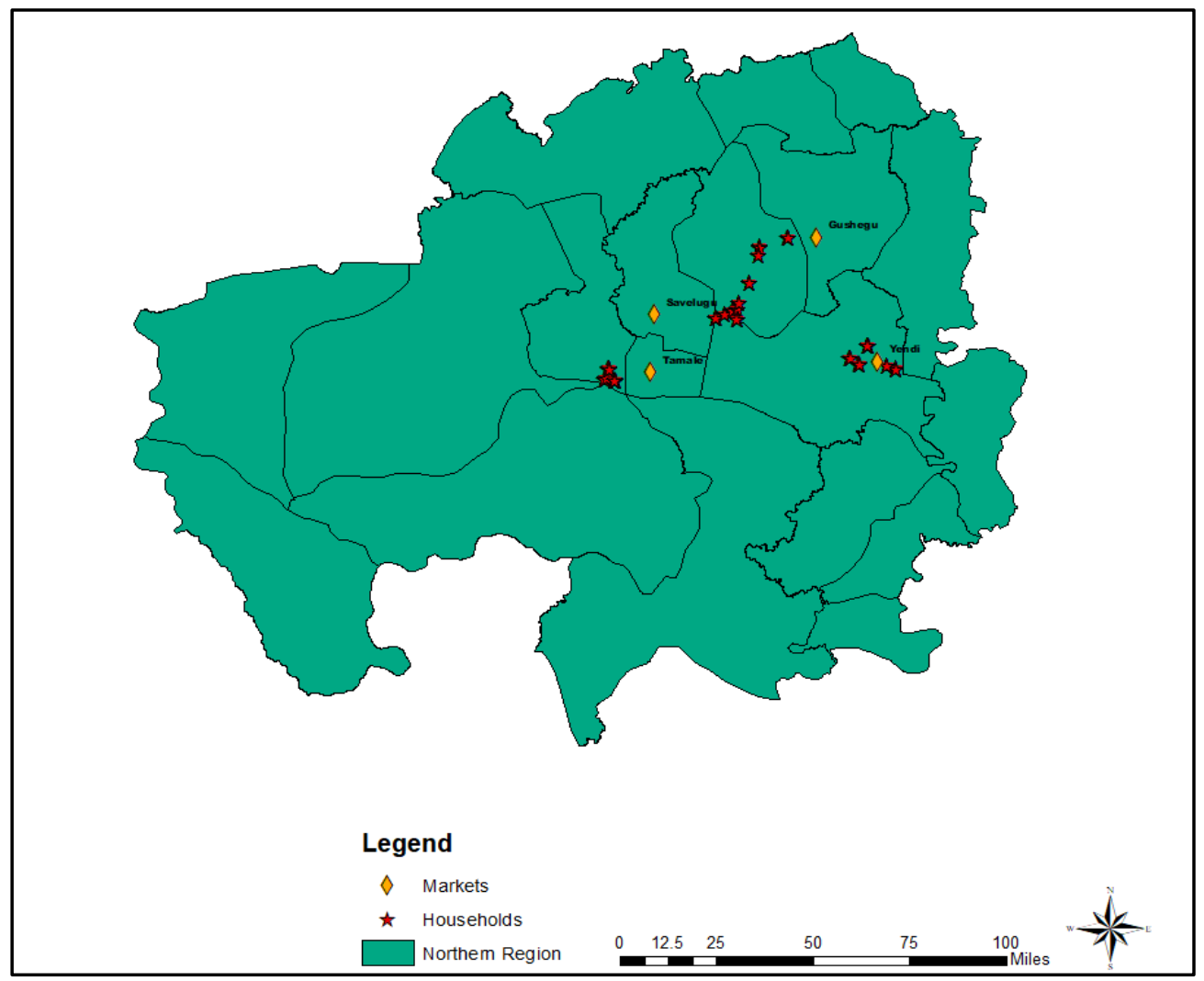

Fig. 2. Administrative map of former Northern Region of Ghana

The data is based on a farmer survey conducted in July 2020. The survey was carried out in four districts namely Tolon, Gushegu, Karaga, and Yendi. A multi-stage sampling technique was used 
in the sampling of the farmers. The first stage involves a purposive selection of four districts in the Northern Region due to the high number of soybean farmers in the selected region and districts. This was followed by a purposive sampling of 15 communities distributed across the four selected districts. The purposive selection of the communities was based on the size of the district, the population of the soybean farmers and the level of crop diversification. Finally, a total of 309 farmers were sampled from the 15 communities using a simple random sampling technique.

Our analysis of land allocation decision is based on the June 2020 planting season. The data collected captured household demographic and farm characteristics, fertilizer use, access to amenities, crop production, sustainable agricultural practices, distribution of farm output, improved seed variety adoption, constraints to crop production, and risk reducing strategies such as the purchase of insurance policy against crop failure. The data captured COVID-19 related information such as level of awareness, education on COVID-19, perceptions of the effect of COVID-19 on agricultural production, food security, and land allocation decisions.

\subsection{Summary statistics}

Table 1 shows the summary characteristics of the explanatory variables used in the model. The results of the study show that $78 \%$ of the sampled farmers are males and the mean age is 41 years with two years of formal education. The distribution of the household members shows an average of two household members across all the different age categories. A sampled farmer has eight dependents on the average and $93 \%$ of the sampled farmers are natives which guarantees access to communal resources such as land for agricultural production. About $27 \%$ of the sampled farmers belong to a farmer-based organization while $20 \%$ hold a leadership position in such association. With respect to institutional variables, the data show that $28 \%$ and $77 \%$ of the sampled farmers 
are related to a political figure and affiliated with a political party which enhances their chance of being considered for developmental projects in the communities. About $50 \%$ of the sampled farmers engage in other economic activities apart from farming. About $37 \%, 20 \%, 19 \%$, and $11 \%$ of the sampled farmers have access to input shop, grain market, credit, and research institute. Farmers in our sample have 18 years of farming experience. While $32 \%$ of the respondents have access to extension services, $2 \%$ and $10 \%$ have insured their farm and engage in contract farming.

Table 1: Summary statistics of respondents

\begin{tabular}{lcccc}
\hline Variable & Mean & Std. Dev. & Min & Max \\
\hline Sex (1=male) & 0.783 & 0.413 & 0 & 1 \\
Age & 40.618 & 12.215 & 20 & 85 \\
Years of education & 2.181 & 4.150 & 0 & 16 \\
Number of males less than 5 years & 1.942 & 1.757 & 0 & 12 \\
Number of females less than 5 years & 1.706 & 1.514 & 0 & 10 \\
Number of males between 6-14 years & 1.926 & 1.735 & 0 & 12 \\
Number of females between 6-14 years & 1.680 & 1.509 & 0 & 8 \\
Number of males between 15-35yrs & 2.110 & 1.836 & 0 & 15 \\
Number of females between 15-35yrs & 2.304 & 1.872 & 0 & 13 \\
Number of males between 36-60 years & 1.285 & 1.061 & 0 & 5 \\
Number of females between 36-60 years & 1.437 & 1.282 & 0 & 8 \\
Number of males above 60 years & 0.333 & 0.537 & 0 & 2 \\
Number of females above 60 years & 0.256 & 0.589 & 0 & 4 \\
Total dependents & 8.443 & 6.783 & 0 & 39 \\
Nativity (1=native) & 0.926 & 0.263 & 0 & 1 \\
Member of FBO (1=yes) & 0.265 & 0.442 & 0 & 1 \\
Hold leadership position (1=yes) & 0.197 & 0.399 & 0 & 1 \\
Related to political figure (1=yes) & 0.275 & 0.447 & 0 & 1 \\
Affiliated to political party (1=yes) & 0.767 & 0.423 & 0 & 1 \\
Engaged in other economic activity (1=yes) & 0.498 & 0.501 & 0 & 1 \\
Access to input shop (1=yes) & 0.369 & 0.483 & 0 & 1 \\
Access to grain market (1=yes) & 0.204 & 0.404 & 0 & 1 \\
Access to credit & 0.194 & 0.396 & 0 & 1 \\
Access to research institute (1=yes) & 0.110 & 0.313 & 0 & 1 \\
Years of farming & 18.104 & 10.546 & 2 & 48 \\
Access to extension services (1=yes) & 0.320 & 0.467 & 0 & 1 \\
Farm insured (1=yes) & 0.019 & 0.138 & 0 & 1 \\
Contract farming (1=yes) & 0.104 & 0.305 & 0 & 1 \\
\hline
\end{tabular}

Table 2 shows the gender disaggregated effect of COVID-19 on agricultural production. Males are generally involved in the cultivation of more crops and as a strategy to cope with COVID-19, males increase farm size to a variety of crops. Based on the result, most males $(44.68 \%)$ increased 
the farm size allocated to the cultivation of soybean. About $28 \%$ and $2 \%$ of males allocated more land to groundnut and rice, respectively due to COVID-19. On the contrary, all the sampled female farmers allocate more land to soybean cultivation. The perceived effect of COVID-19 on agricultural production by farmers was mixed. A large proportion (68\%) of male farmers perceived COVID-19 to have a negative (disruptions in the factor input market, food system and transportation sector) effect on agricultural production. About $26 \%$ of male farmers perceive COVID-19 to have both negative and positive effects on agricultural production. Alternatively, $48 \%$ of female farmers perceived COVID-19 to have both positive and negative effects on agricultural production while $39 \%$ indicated that the effect of COVID-19 on agricultural production is negative. The chi-square test shows that there is a significant association between the sex of a farmer and their perceived effect of COVID-19 on agricultural production. The main sources of sensitization on COVID-19 for both male and female farmers are Non-governmental organizations (NGOs) and Agricultural extension agents (AEAs). Most farmers (50\% males and $58 \%$ females) reported soybean as the most profitable crop due to COVID-19 due to inflationary price effects in the consumption areas of Ghana. 
Table 2: COVID-19 effect on agricultural production

\begin{tabular}{lccc}
\hline Variable & Male & Female & Chi2 \\
\hline Increase crop farm size due to COVID-19 & & & \\
Maize & 25.33 & 0.00 & 2.36 \\
Soybean & 44.68 & 100.00 & \\
Rice & 2.13 & 0.00 & \\
Groundnut & 27.66 & 0.00 & \\
Effect of COVID-19 on agricultural production & & & \\
Negatively & 67.77 & 38.81 & $18.63^{* * *}$ \\
Positively & 6.61 & 13.43 & \\
Both & 25.62 & 47.76 & \\
Source of sensitization of COVID-19 & & & \\
AEAs & 41.10 & 41.67 & 2.18 \\
NGOs & 50.68 & 58.33 & \\
Research Organization & 8.22 & 0.00 & \\
Most profitable crop due to COVID-19 & & & \\
Soybean & 50.41 & 58.21 & 4.29 \\
Maize & 28.51 & 16.42 & \\
Groundnut & 19.42 & 22.39 & \\
Rice & 1.65 & 2.99 & \\
\hline
\end{tabular}

Figure 3 shows the proportion of respondents who cultivated various crops. Comparatively, a higher proportion of the sampled respondents cultivate more maize and soybean than groundnut and rice. Less than 13\% of the sampled respondents cultivate rice and groundnut for 2018, 2019, and 2020 cropping season. The 2019 production year witnessed the highest number of farmers cultivating maize, soybean, and groundnut. The proportion of farmers who cultivated soybean $(85 \%)$ is higher than those who cultivated maize $(78 \%)$ and groundnut (23\%) in 2019. The 2020 production season witnessed a $41 \%$ of the sampled respondents cultivating soybean while $44 \%$ cultivates maize. The decline in the number of farmers cultivating maize and soybean may be attributed to farmers cultivating other crops that are not captured by the survey. With respect to soybean, buyers were unavailable at the time of sale due to the partial lockdown which led to a deflationary price effect in the production regions. In view of this, some of the farmers decided to 
shift to other crops. However, the reduction in the number of farmers cultivating maize and soybean do not reflect a decrease in land allocation.

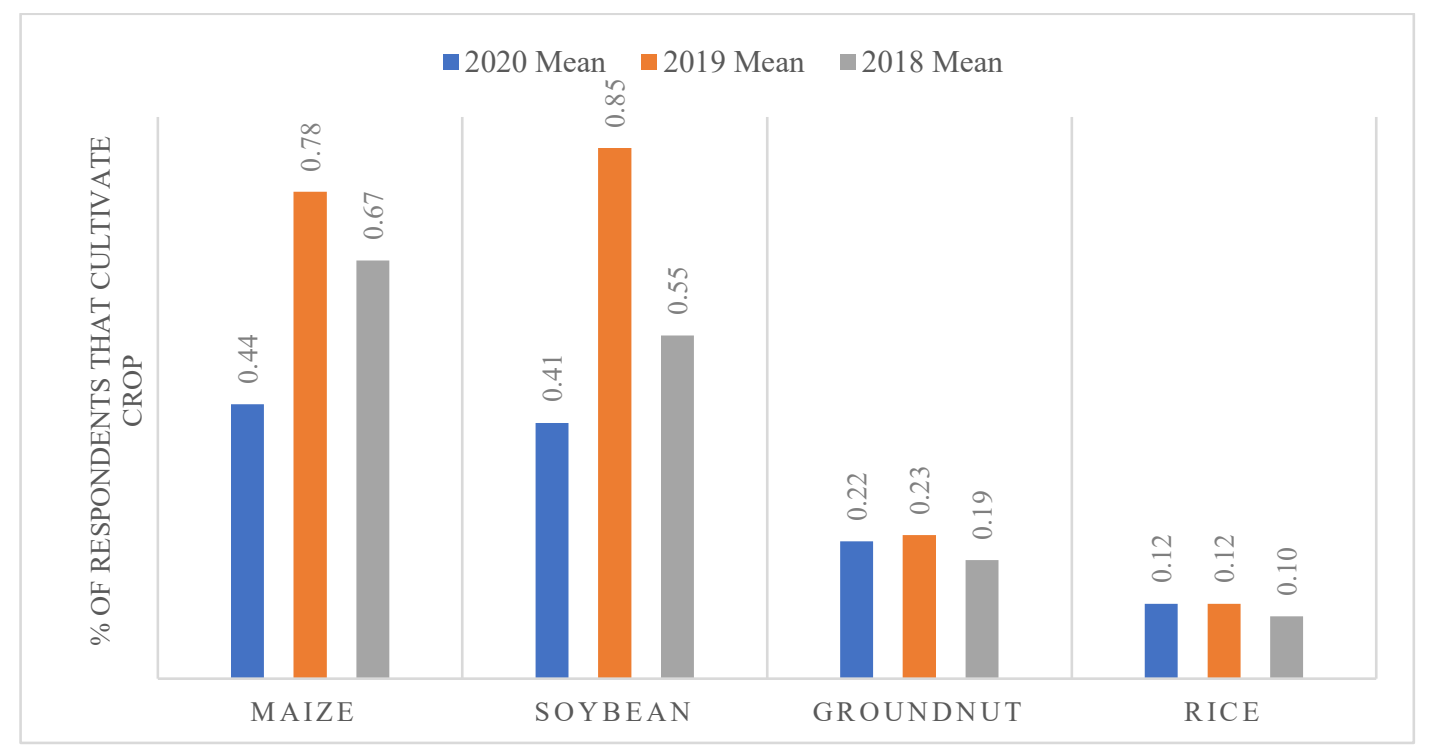

Fig. 3. Crop production by crop type and year

Figure 4 shows the rankings of maize, soybean, rice, and groundnut based on their importance to utilization and income. Generally, a greater proportion of farmers $(62 \%)$ consider maize as the most important crop while $67 \%$ consider rice as the least important crop among the crop portfolios. According to the farmers interviewed, maize is a food security crop and mainly consumed and the surplus sold to generate income for the purchase of non-farm commodities. About $50 \%$ and $52 \%$ of the farmers ranked soybean and groundnut as very important and important, respectively. A large proportion of the farmers interviewed cultivate legumes to generate income to support farm expansion and other important needs of households. Compared to $9 \%$ who ranked maize as important, about $19 \%$ of the farmers ranked soybean as important. 


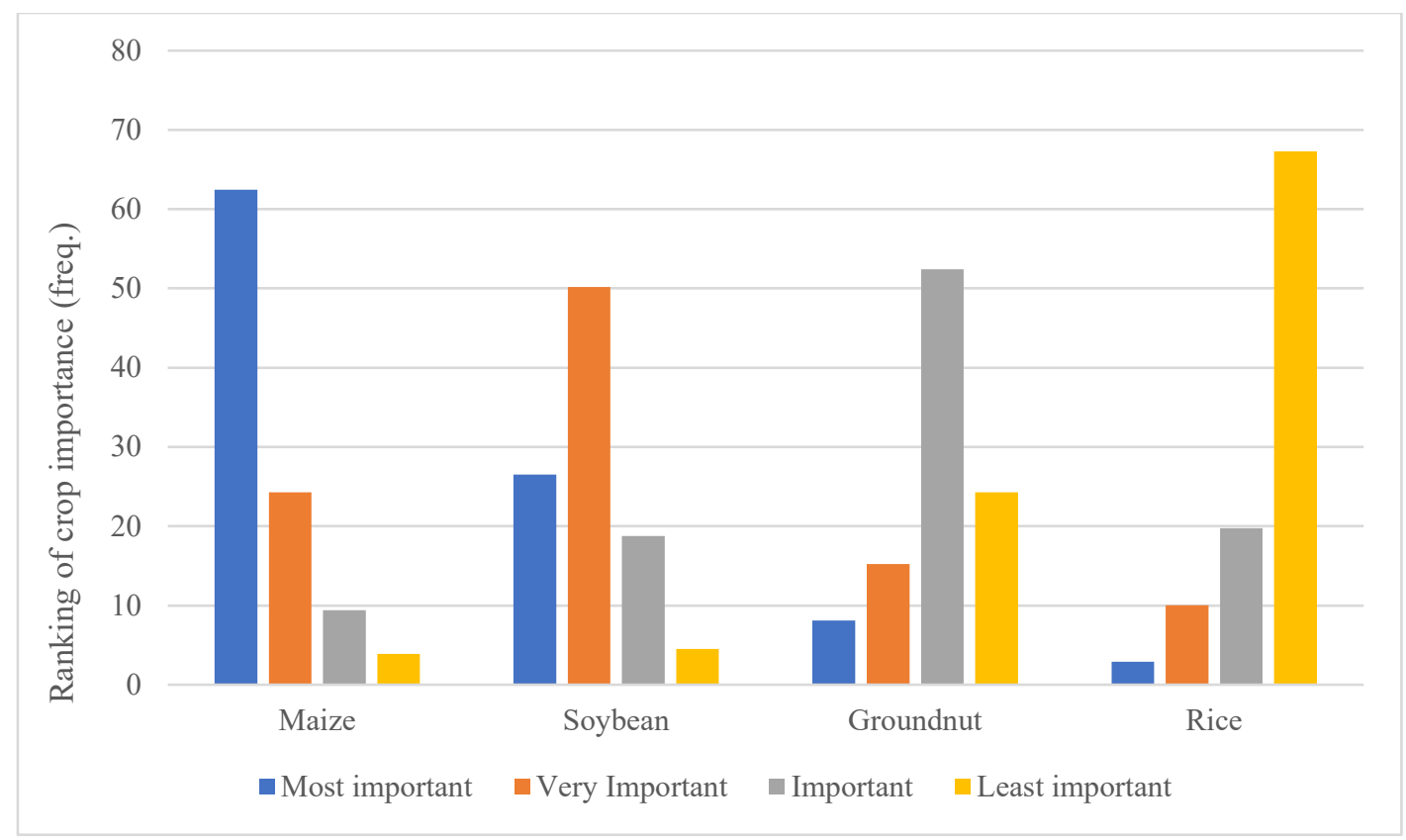

Fig. 4. Crop ranking based on utilization and income

\section{Results and discussion}

\subsection{Farmer awareness and perceptions of COVID-19 pandemic on farm production}

Table 3 reports farmers' awareness of COVID-19 and their perceptions of COVI-19 related factors on agricultural production. There is a high level of COVID-19 awareness among farmers in the study area. About $98 \%$ of farmers are aware of COVID-19. Given the high level of awareness, it is expected that farmers may take safety precautionary steps to curb the spread of the virus and strategically plan their farming activities. A similar result was also observed for both men (98.3\%) and women farmers $(95.5 \%)$ in the study area. Despite the high level of awareness, the data show that only $33 \%$ of the farmers have been educated or sensitized on the COVID-19 safety protocols. These sensitizations were done by AEAs, NGOs, and research organizations. The result indicates that the need for further education to reduce the potential risk of community spread and impact of the COVID-19 on agricultural production. About 58\% of the respondents opined that COVID-19 will influence agricultural production and $11.3 \%$ of the farmers indicate that COVID-19 influences 
their current production decisions. The farmers anticipate that lack of buyers, high cost of laborers, and high input prices will affect the current production decisions. The result shows that about $36 \%$ of the farmers indicated that their production decisions for the 2020 cropping season were influenced by the current market prices of food and commercial crops. This indicates that farmers were responding positively by cultivating crops with relatively high output prices. Generally, relatively few farmers $(41.3 \%)$ allocated more land for the cultivation of soybean and maize. Comparatively, the allocation of more land for the cultivation of specific crops was higher among men $(24.0 \%)$ than women $(13.4 \%)$. Less than $7 \%$ of the farmers changed their cropping pattern due to COVID-19 and 55\% stated that labor for agricultural production is readily available. About $46 \%$ of the sampled farmers indicate that more family labor was used in the previous cropping season (2019) relative to the current cropping season (2020). The use of more family labor for agricultural production in the previous cropping season is relatively higher among women (49\%) than men $(45 \%)$.

Table 3: Awareness and perceptions of COVI-19 pandemic on crop production

\begin{tabular}{|c|c|c|c|c|c|c|}
\hline \multirow[b]{2}{*}{ Variable } & \multicolumn{2}{|c|}{ Males } & \multicolumn{2}{|c|}{ Females } & \multicolumn{2}{|c|}{ Pooled } \\
\hline & Mean & Std. Dev. & Mean & Std. Dev. & Mean & Std. Dev. \\
\hline Awareness of COVID-19 & 0.983 & 0.128 & 0.955 & 0.208 & 0.977 & 0.149 \\
\hline COVID-19 will influence agriculture & 0.640 & 0.481 & 0.373 & 0.487 & 0.583 & 0.494 \\
\hline Sensitization/education on COVID-19 & 0.331 & 0.471 & 0.358 & 0.483 & 0.337 & 0.473 \\
\hline COVID-19 influences crop production decision & 0.116 & 0.321 & 0.104 & 0.308 & 0.113 & 0.317 \\
\hline Current market price influence production decisions & 0.157 & 0.365 & 0.134 & 0.344 & 0.152 & 0.360 \\
\hline Allocation of more land to a specific crop & 0.240 & 0.428 & 0.134 & 0.344 & 0.217 & 0.413 \\
\hline Current crop cultivated due to COVID-19 & 0.050 & 0.218 & 0.104 & 0.308 & 0.061 & 0.241 \\
\hline Readily available labor & 0.595 & 0.492 & 0.388 & 0.491 & 0.550 & 0.498 \\
\hline More family labor use than previous season & 0.450 & 0.499 & 0.493 & 0.504 & 0.460 & 0.499 \\
\hline Observation & 242 & & 67 & & 309 & \\
\hline
\end{tabular}


Figure 5 shows the change in land allocation decisions for maize, soybean, groundnut, and rice from 2018 to 2020 cropping season. Generally, the area under maize cultivation is relatively higher than the area under soybean production. The area allocated to soybean production has been increasing from 2.69 acres, 3.05 acres, and 3.13 acres in 2018, 2019, and 2020, respectively. Similarly, the area allocated to maize production increased from 3.45 acres in 2018 to 4.1 acres in 2019 but decreased to 3.69 acres in 2020 . The relatively high acreage of maize highlights the importance of maize to farmers in the study area. However, in 2020 the result shows a change in the land allocation decision between maize and soybean. While the area allocated to maize production declined, the area under soybean cultivation increased.

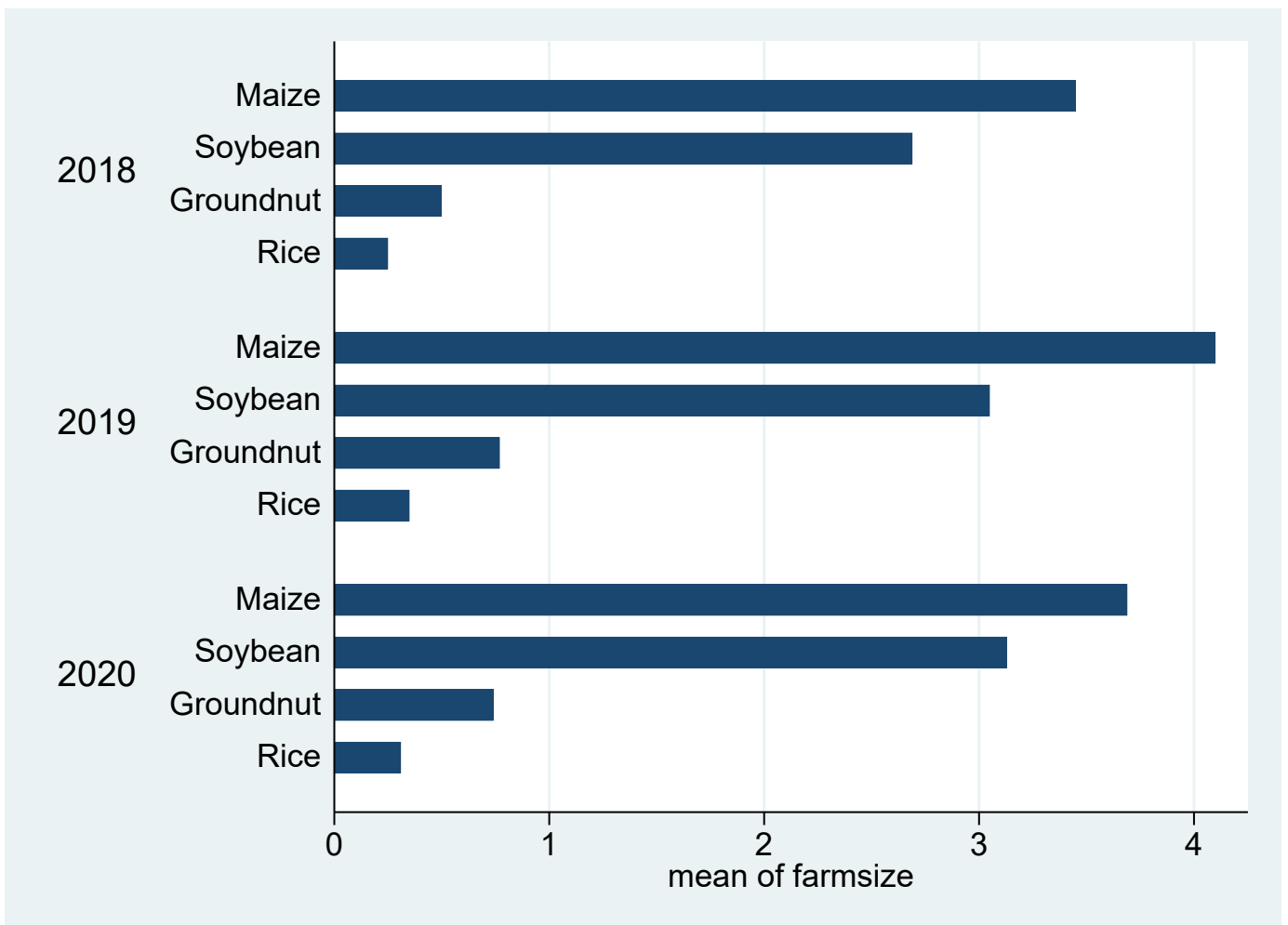

Fig. 5. Land allocation decisions across crop types and year

The area allocated to groundnut and rice cultivation from 2018 to 2020 is less than one acre. The area under groundnut production increased from 0.50 acres in 2018 to 0.77 acres in 2019 and 
decreased to 0.74 acres in 2020. The area under rice cultivation increased from 0.25 acres in 2018 to 0.35 acres in 2019 and decreased to 0.31 acres in 2020. Comparatively, the crop area under maize and soybean are relatively higher than the area under groundnut and rice cultivation. Except for soybean, all the crops witnessed a decline in the area under cultivation in 2020.

Figure 6 shows the levels of agreement regarding farmers perceptions about COVID-19 effect on household agricultural production, marketing, household consumption, and nutrition outcomes. Generally, farmers perceive soybean production to be the most profitable crop during the COVID19 pandemic which is followed by maize, groundnut, and rice production. According to the farmers, the price of soybean is likely to increase in the urban markets due to the low supply of soybeans resulting from the partial lockdown. However, the disruptions in the transportation sector make transportation of soybean to the urban markets very costly.

With respect to the effect of COVID-19 decreasing output prices, the majority (61\%) of the sampled farmers agreed with the statement. The farmers indicated that the restrictions due to the partial lockdown created a deflationary price effect in the production zones due to the low demand of soybean by the traders. The result shows variations in the level of agreement in terms of the effect of COVID-19 on input prices. Consistent with the output price perceptions, about $61 \%$ of the sampled farmers agree that COVID-19 will increase input price. The perceptions of farmers with respect to the increase in input prices may be attributed to the disruptions in trade due to the closure of the borders. However, only 3\% stated that COVID-19 has no impact on input prices. According to the sampled farmers, COVID-19 is perceived to limit access to input and output markets. Fifty-eight percent of the respondents agree that COVID-19 limits access to input and 
output markets while $11 \%$ indicate no impact. The high cost of transportation may be accounting for the present findings.

Farmers' perceptions about a decrease in food availability due to COVID-19 are quite mixed. While $36 \%$ of the sampled farmers agree with the statement, $40 \%$ disagree and $24 \%$ stated no impact. Fifty-one percent of the sampled farmers agree that the COVID-19 pandemic will decrease the flow of remittances to households while $36 \%$ disagree with the assertion. The economic shock due to the COVID-19 pandemic has led to the loss of migrant jobs. This has a ripple effect on the flow of remittances to the left-behind. Most of the farmers (51\%) in our sample disagree with the perception that COVID-19 pandemic has led to panic buying of other essentials through the sale of stored food.

Our results show that $56 \%$ of the respondents agree with the perception that farmers are incapable of maintaining their farm activities due to loss of crop income by the COVID-19 pandemic. The farmers indicated that failure to sell their products to their loyal buyers from the urban areas resulted in a deflationary price effect especially in the production areas. This led to a decline in their crop incomes thus affecting their farm-level investment. The majority (54\%) of the respondents agree that COVID-19 impacts negatively on farmers' health to the extent of limiting their capacity to maintain their farm activities. The community spread of COVID-19 increases farmers' risk of contracting the disease which may reduce farm productivity. Similarly, labor availability becomes a constraint thus reducing farmers' land allocation. 
Farmers perceive that the COVID-19 pandemic reduces their purchasing power due to a decline in the household income. Generally, $56 \%$ of the farmers agree with the perception. However, $34 \%$ of the respondents disagree with the assertion. Consistent with the previous assertion, a decline in output price will subsequently, result in a fall in crop income and farmers' purchasing power.

The perception that the COVID-19 pandemic will increase the prioritization of poor-quality products among farmers is mixed. While $42 \%$ agree with the perception, $41 \%$ disagree. The result indicates that while some farmers prioritize poor nutrition quality products, others do not. However, $17 \%$ of the respondents indicate no impact. Similarly, farmers are indifferent about the perception that COVID-19 will lead to a reduction in the per capita meal due to increase pressure of family members returning from other areas. However, $18 \%$ stated no impact on COVID-19.

In summary, the data show agreement in most of the farmers' perceptions regarding output price, input price, limited access to input and output markets, farmers incapability to maintain farm activities due to loss of crop income, reduction in the purchasing power due to a decline in the household income, and farmers' inability to maintain their farm activities due to health implications. However, the perceptions about a decrease in food availability, increase in the prioritization of poor-quality products, and reduction in the per capita meal are quite mixed. The majority of the farmers disagree with the perception of increase in panic buying of other essentials through the sale of stored food. 

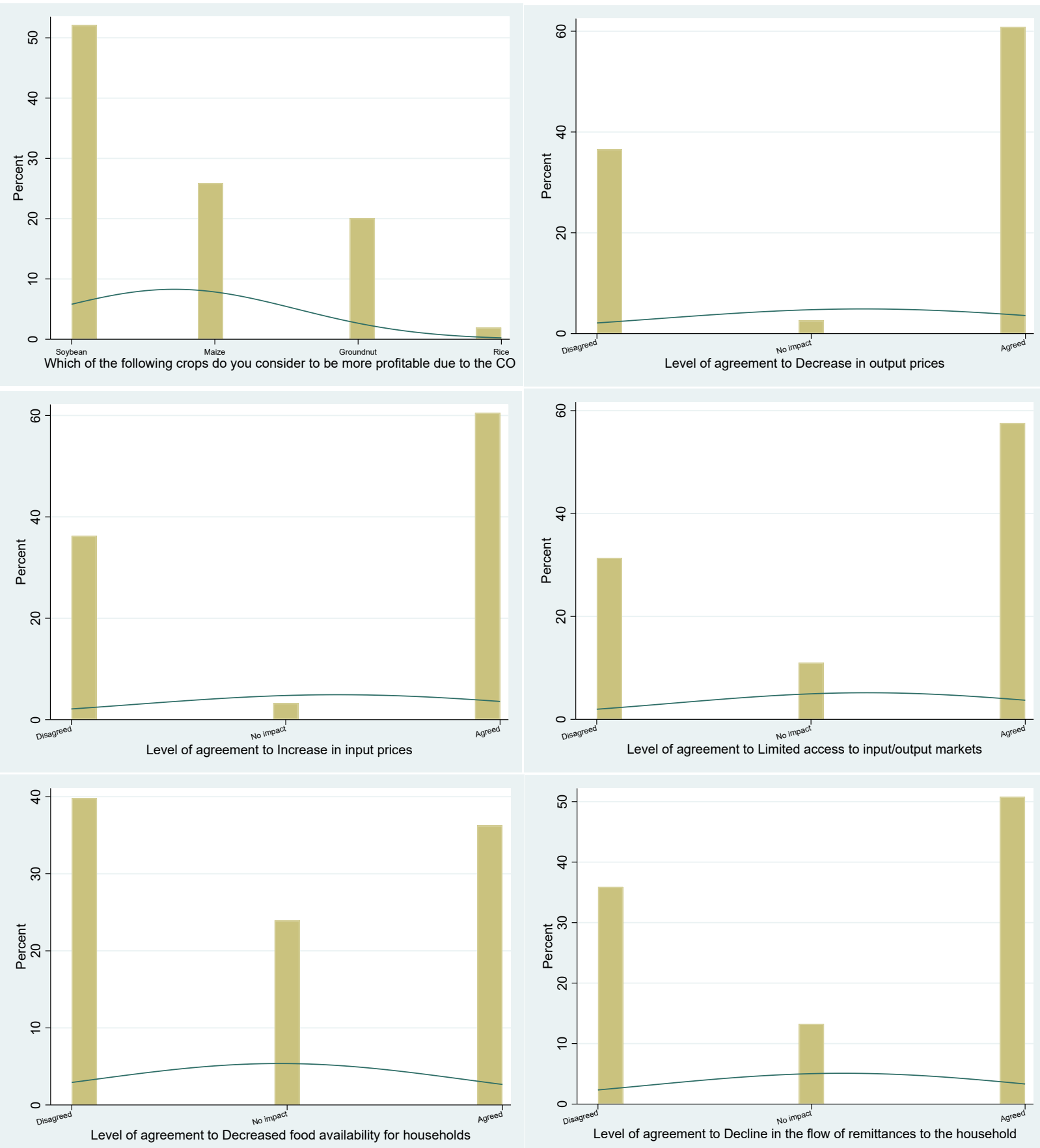

Fig. 5a. Level of agreement about COVID-19 perception effect on household wellbeing. 

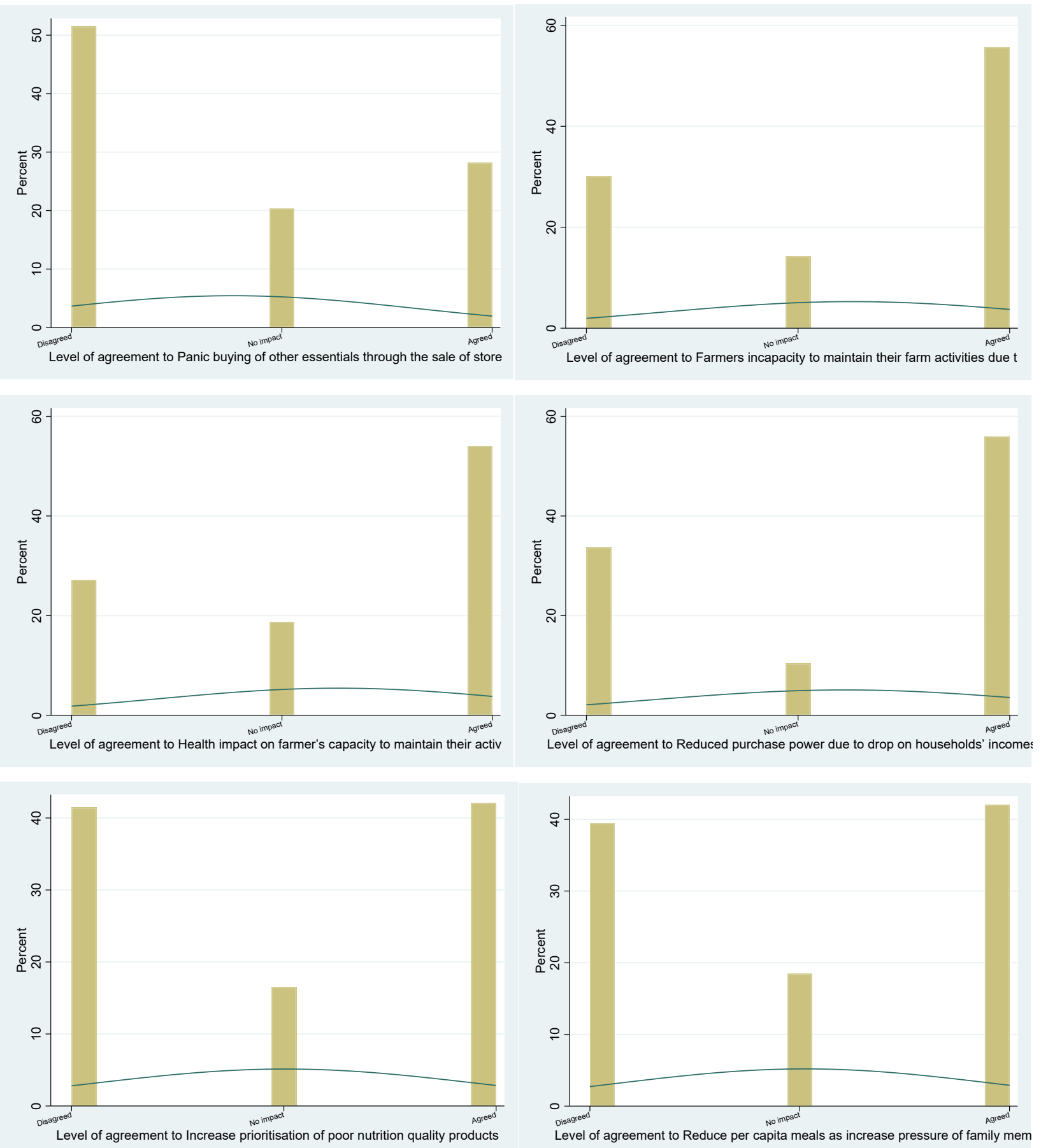

Fig. 5b. Level of agreement about COVID-19 perception effect on household wellbeing. 


\subsection{Probit estimates of factors influencing crop land allocation decisions}

Table 6 reports the probit estimation of the factors influencing the crop (soybean) land allocation decisions by farmers due to the COVD-19 pandemic. The dependent variable (dummy) measures if farmers were willing to allocate more land to soybean production due to the COVD-19 pandemic. The marginal effects are reported while the clustered standard errors are in parentheses. Model 1 is the base model that did not account for political and COVID-19 controls. Model 2 accounted for political controls while model 3 accounted for both political and COVID-19 controls. There is model improvement across the three models based on the Pseudo R-square value. The Pseudo R-square value increased from 0.145 to 0.320 after controlling for both political and COVID-19 variables. The probability of changing cropland allocation decisions are significantly influenced by age, economic active members within the household, distance to input shop, access to research institute, years of farming experience, access to input shop, relationship with a political figure, perception of the negative effect of COVID-19 on agriculture, perception of COVID-19 effect on crop choice, and current cropping due to the COVID-19 pandemic.

The probability of allocating more land to soybean production is $5 \%$ lower among older farmers relative to the young farmers. The result suggests that younger farmers are more likely to change their land allocation decisions due to COVID-19. Younger farmers are more likely to take risk relative to older farmers (Manda et al., 2016) thus are more likely to allocate more land to crops with relatively higher anticipated price increase due to the COVID-19 pandemic. The result suggests that a unit increase in the number of adults economically active household members is likely to increase the probability of making land allocation decisions to soybean by $1.4 \%$. Adult economic active members are a potential source of financial support for farm households. 
Households with more economic active members are more likely to contribute financially towards more profitable crops like soybean, thus the higher the probability of allocating more land to profitable crops. Distance to the input shop is positively associated with land allocation decisions. A unit increase in the distance from homestead to input shop increases the probability of allocating more land to soybean by 7\%. Long-distance is associated with high transaction costs. A relatively high transaction cost will increase input cost or may prevent farmers from using modern inputs which may affect their production and land allocation decisions. Framers who travel a longer distance to access specific crop inputs are more likely to allocate less land to soybean irrespective of the profitability of the crop. The high cost of transportation may increase the overall cost of production thus reducing the area under cultivation given that households are income constrained. Access to research institutions is positively associated with land allocation decisions. The result shows that farmers who have access to research institutions are $19 \%$ more likely to make a land allocation decision relative to farmers who have no access to a research institution.

Research institutions serve as a source of agricultural information and capacity building for farmers. Most of the agricultural research institutions support farmers with new technologies that are disseminated by agricultural extension agents. Farmers with adequate and critical information can make more accurate land allocation decisions with minimal losses. Several studies (Van Campenhout et al., 2017; Jack, 2013) have highlighted the importance of critical information in enhancing farm production decisions.

With respect to the political controls, we observed a positive association between farmer relation with a political figure and soybean land allocation decision. Farmers who are related to a political 
figure in their community are $14 \%$ more likely to make cropland allocation decisions relative to those who have no relationship with a political figure. Farmers who are related to politicians are more likely to benefit from government projects that provide agricultural input support (e.g. fertilizer and seed) to smallholder farmers. The type of input support is likely to influence cropland allocation decisions. Ragasa \& Mazunda (2018), Ricker-Gilbert et al (2011), and Seck (2016) have shown that access to a member of parliament or a political leader has an implication on an individual farming decision.

With respect to the COVID-19 controls, the result shows that perception of the negative effect of COVID-19 on agriculture is positively associated with cropland allocation decisions. Some of the negative effects include lack of support from NGOs, high input price and unavailability of some agricultural inputs, unavailability of labor, lack of remittances, limited access to output markets, and low output price. Farmers who perceive that COVID-19 pandemic will affect agricultural production negatively are $8 \%$ more likely to make cropland allocation decisions to soybean relative to farmers with different perceptions of COVID-19 on agricultural production. A negative agricultural shock is likely to influence the type of farm investment and the allocation of resources among different crop portfolios. The result confirms the findings of Shikuku et al. (2017) who found that smallholders exposed to negative shocks are less likely to invest in soil fertility and land management practices since the initial investments are high and the benefits can usually only be derived in the future. According to Waldman et al. (2017), agricultural shocks influence farmers to make risk-averse decisions that have the potential of influencing farm-level performance. Similarly, farmers are more likely to invest in short term improved technologies with lower risk relative to long term investment with higher risk (Shikuku et al., 2017). 
Table 4: Factors influencing soybean land allocation decision - probit estimates

\begin{tabular}{|c|c|c|c|}
\hline Variables & $\begin{array}{c}\text { Marginal } \\
\text { effect }\end{array}$ & $\begin{array}{c}\text { Marginal } \\
\text { effect }\end{array}$ & $\begin{array}{c}\text { Marginal } \\
\text { effect }\end{array}$ \\
\hline & (Model 1) & (Model 2) & (Model 3) \\
\hline Age & $\begin{array}{c}-0.007 * * \\
(0.003)\end{array}$ & $\begin{array}{c}-0.007 * * \\
(0.003)\end{array}$ & $\begin{array}{c}-0.005^{* *} \\
(0.003)\end{array}$ \\
\hline Sex $(1=$ Male $)$ & $\begin{array}{c}0.044 \\
(0.086)\end{array}$ & $\begin{array}{c}0.000 \\
(0.085)\end{array}$ & $\begin{array}{c}0.044 \\
(0.068)\end{array}$ \\
\hline Education years & $\begin{array}{c}0.008 \\
(0.005)\end{array}$ & $\begin{array}{c}0.008 \\
(0.005)\end{array}$ & $\begin{array}{c}0.005 \\
(0.004)\end{array}$ \\
\hline Males between $15-35$ years & $\begin{array}{c}0.006 \\
(0.011)\end{array}$ & $\begin{array}{c}0.001 \\
(0.012)\end{array}$ & $\begin{array}{c}0.001 \\
(0.012)\end{array}$ \\
\hline Males between $36-60$ years & $\begin{array}{l}-0.025 \\
(0.028)\end{array}$ & $\begin{array}{l}-0.006 \\
(0.029)\end{array}$ & $\begin{array}{l}-0.004 \\
(0.025)\end{array}$ \\
\hline Adult economic active members & $\begin{array}{c}0.014 \\
(0.010)\end{array}$ & $\begin{array}{c}0.012 \\
(0.008)\end{array}$ & $\begin{array}{l}0.014^{*} \\
(0.008)\end{array}$ \\
\hline Dependents & $\begin{array}{l}-0.003 \\
(0.003)\end{array}$ & $\begin{array}{l}-0.002 \\
(0.003)\end{array}$ & $\begin{array}{l}-0.001 \\
(0.003)\end{array}$ \\
\hline Member of FBO & $\begin{array}{l}-0.065^{*} \\
(0.034)\end{array}$ & $\begin{array}{c}-0.087 * * \\
(0.034)\end{array}$ & $\begin{array}{l}-0.028 \\
(0.030)\end{array}$ \\
\hline Distance to input shop & $\begin{array}{c}0.009 * * * \\
(0.002)\end{array}$ & $\begin{array}{c}0.008 * * * \\
(0.002)\end{array}$ & $\begin{array}{c}0.007 * * * \\
(0.002)\end{array}$ \\
\hline Access to research institute & $\begin{array}{c}0.215 * * * \\
(0.077)\end{array}$ & $\begin{array}{c}0.223 * * * \\
(0.074)\end{array}$ & $\begin{array}{c}0.193 * * * \\
(0.073)\end{array}$ \\
\hline Years of farming & $\begin{array}{c}0.009 * * * \\
(0.003)\end{array}$ & $\begin{array}{c}0.009 * * * \\
(0.003)\end{array}$ & $\begin{array}{c}0.005 * * \\
(0.002)\end{array}$ \\
\hline Access to input shop & $\begin{array}{c}0.128^{* *} \\
(0.054)\end{array}$ & $\begin{array}{c}0.127 * * \\
(0.056)\end{array}$ & $\begin{array}{l}0.101^{*} \\
(0.056)\end{array}$ \\
\hline Access to credit facility & $\begin{array}{l}-0.108 \\
(0.068)\end{array}$ & $\begin{array}{c}-0.121 * * \\
(0.061)\end{array}$ & $\begin{array}{l}-0.088 \\
(0.059)\end{array}$ \\
\hline Access to grain market & $\begin{array}{l}-0.009 \\
(0.080)\end{array}$ & $\begin{array}{l}-0.036 \\
(0.072)\end{array}$ & $\begin{array}{l}-0.059 \\
(0.049)\end{array}$ \\
\hline Access to extension services & $\begin{array}{c}0.000 \\
(0.045)\end{array}$ & $\begin{array}{c}0.003 \\
(0.039)\end{array}$ & $\begin{array}{l}-0.006 \\
(0.044)\end{array}$ \\
\hline Farm insurance & $\begin{array}{c}0.084 \\
(0.144)\end{array}$ & $\begin{array}{c}0.180 \\
(0.160)\end{array}$ & $\begin{array}{c}0.222 \\
(0.155)\end{array}$ \\
\hline Distance to output markets & $\begin{array}{c}-0.006^{* *} \\
(0.003)\end{array}$ & $\begin{array}{l}-0.006^{*} \\
(0.003)\end{array}$ & $\begin{array}{l}-0.004 \\
(0.002)\end{array}$ \\
\hline Political controls & & & \\
\hline Related to political figure & & $\begin{array}{c}0.189 * * * \\
(0.067)\end{array}$ & $\begin{array}{c}0.143 * * \\
(0.063)\end{array}$ \\
\hline Affiliated to political party & & $\begin{array}{c}0.074 \\
(0.068)\end{array}$ & $\begin{array}{c}0.039 \\
(0.068)\end{array}$ \\
\hline COVID-19 controls & & & \\
\hline Education on COVID-19 & & & $\begin{array}{l}-0.028 \\
(0.042)\end{array}$ \\
\hline Negative COVID-19 effect on agriculture & & & $\begin{array}{l}0.076^{*} \\
(0.043)\end{array}$ \\
\hline COVID-19 influence crop choice & & & $\begin{array}{l}0.152^{*} \\
(0.086)\end{array}$ \\
\hline Current cropping due to COVID-19 & & & $\begin{array}{c}0.526^{* * *} \\
(0.089)\end{array}$ \\
\hline Pseudo R2 & 0.145 & 0.198 & 0.320 \\
\hline Observations & 309 & 309 & 309 \\
\hline
\end{tabular}


Farmers who perceive COVID-19 to influence crop choice is $15 \%$ more likely to make cropland allocation decision to soybean compared to those who do not perceive COVID-19 to have any influence on crop choice. The data shows that about $47 \%$ of the farmers are shifting resources towards soybean production given that prices of soybean are increasing more than the prices of cereals and other legumes like groundnut due to the COVID-19 pandemic in the urban markets. The current cropping practices due to COVID-19 have a significant and positive association with crop land allocation decision. The probability of making cropland allocation decision is $53 \%$ higher among farmers whose current crop practices is as a result of the COVID-19 relative to farmers who use different cropping practices. For example, farmers whose current cropping practices (such as intercropping, monocropping or mixed cropping) are as a result of the COVID19 pandemic are more likely to make cropland allocation decision among the different crops in order to hedge against crop losses.

\subsection{Factors determining crop land use}

Table 7 reports the results of the SUR. The first four columns show the results of the factors influencing land allocated to maize, soybean, groundnut, and rice while the last two columns show the results of the factors influencing cereal and legume land allocation decisions. All the variables presented in Table 7 significantly influenced land allocation decisions except age and sex. The Rsquared value indicates that between $15 \%$ and $53 \%$ of the variations in the land allocation decision is explained by the independent variables (socio-economic, production, political, external shocks, and institutional factors).

With respect to the socioeconomic factors, years of education is associated with a positive effect on land allocated to soybean and legumes in general. This indicates that educated farmers are more 
likely to allocate more of the cropland to legume production. A unit increase in the years of formal education increases the land allocated to soybean and legume by 0.06 acres and 0.08 acres, respectively. Education empowers individuals to make an informed decision about food security and income. The result contradicts the findings of Adjimoti (2018) who found that primary education attainment increases the land allocated to cereals. On the contrary, Chibwana et al. (2012) showed that educated household heads allocate less land to maize and more to other crops (groundnut, beans, and all other annual crops) than households where the head has no education. Our result suggests that educated farmers are more likely to make decisions that will favor commercial crops relative to food crops.

Member of farmer association is significant and positively associated with both cereal and legume land allocation. Compared to non-members of FBO, farmers that belong to FBOs are more likely to increase the land allocated to cereals and legumes by 0.88 acres and 1.23 acres, respectively. Group membership guarantees access to agricultural inputs, credit, knowledge sharing, and support for members. Most farmer groups are based on specific crops that may influence the land allocation decisions. Our result is consistent with the findings of Kokoye et al. (2013) and Nguyen et al. (2017) who found a positive relationship between group membership and land allocated to legumes and cereals, respectively.

For institutional factors, farmers who have access to input shop decreases the land allocated to cereals by 0.99 acres compared to farmers who do not have access to the input shop. Similarly, distance to input shop which captures transaction cost reduces the area of land allocated to cereals by 0.03 acres. The results suggest that access to input shop do not necessarily guarantee the 
expansion of cropland. Costs related to high transaction costs associated with distance and high cost of inputs may discourage farmers from expanding their farms. Despite the importance of credit in agricultural production decisions, our results show no significant effect of credit on cropland allocated to both legumes and cereals. However, some studies have shown that credit access increase area allocated to other annual crops in Thailand (Nguyen et al., 2017) and cash crops in Benin (Kokoye et al., 2013).

Compared to farmers who do not have access to grain markets, farmers who have access to grain market increases the land allocated to legumes by 0.78 acres. A readily available market reduces farmers' high risks of theft, postharvest losses, and high cost of storage. Contrary to our expectations, farmers with access to research institutions reduce their area under legume cultivation by 1.06 acres. Research institutions have been at the forefront of agricultural technology development. Farmers may have access to research institutions but may not have access to the agricultural technologies related to legumes thus are more likely to reduce their land allocation. In recent times, there has been strong advocacy for sustainable land intensification for effective monitoring and management of small farms (Struik \& Kuyper, 2017). Farmers may be responding to this call by reducing the area under crop cultivation. Tamimie \& Goldsmith (2019) found that crop complexity or newness reduces the crop area allocated to soybean cultivation in Ghana.

Farmers who have formally subscribed to an insurance policy against the risk of crop failure are more likely to increase the area under cereal production by 3.98 acres. Farm insurance serves as a risk-reducing mechanism which allows farmers to expand given that they do not bear the entire 
risks of crop failure, theft, and low output price. In order to estimate the effect of the price at different markets, we use farmer geo-codes to estimate the distance to the nearest market where they either buy or sell food commodities for household consumption. Distance to output markets reflects different output prices faced by the farmers. The area allocated to cereal and legume production increases by 0.08 acres and 0.05 acres, respectively for a unit increase in the distance to output markets. The results suggest that farmers are responding appropriately by allocating more land to cereal production relative to legume production. This could be a case where household cares more about food security relative to investment in cash crop. The number of extension visits increases the area allocated to soybean by 0.27 acres. Contrary to our expectation, Kokoye et al. (2013) found a reverse relationship between extension access and area allocated to cereal production. The measurement of extension access may be a contributing factor given that they use a dummy variable to capture access while we use the number of extension visits.

With respect to production factors, the number of laborers used for sowing soybean seeds increases the area under cereal and legume production by 0.08 acres and 0.31 acres, respectively. The result confirms the theory of joint production where an increase in the labor input of soybean increases the labour input of maize. The number of laborers used for sowing maize seeds decreases the area under legume production by 0.09 acres with no significant effect on the maize production area. Consistent with the a priori expectation, an increase in the price of soybean decreases the area under cereal production by 2.19 acres. Farmers are more likely to increase the area under legume production when they expect the price of legumes to increase relative to the price of cereals. The amount of labor available for weeding the maize plot and users of inorganic fertilizer on maize plot increases the area under cereal production by 0.21 acres and 1.33 acres, respectively. The 
result is consistent with the findings of Kokoye et al. (2013) who found a positive association between fertilizer use and cereal land allocation.

Political factors such as the relation with a political figure and affiliation to a political party significantly influenced land allocation decisions. Ragasa \& Mazunda (2018), Ricker-Gilbert et al (2011), and Seck (2016) found that access to a Member of Parliament or political leaders has an implication on an individual farming decision. Farmers who are related to a political figure are more likely to reduce the land allocated to legume by 0.55 acres relative to farmers who are not related to a political figure. Political affiliation increases land allocation to cereals by 1.18 acres. The result is not surprising given that political affiliation guarantees access to developmental projects that provide input support to smallholder farmers. The current policy on "planting for food and job" provides subsidized inputs to farmers. Most of the government development interventions target maize farmers; thus, farmers who are affiliated to the political party in power have a higher chance of getting such input supports. Farmers who have the assurance of getting agricultural input support will be more willing to allocate more land to cereal production relative to other crops. Given that most of the projects target maize production, farmers who are related to political figures may shift land resources towards maize production at the expense of legumes thus the negative association with legumes. 
Table 7: Determinants of crop land use choices (SUR model results)

\begin{tabular}{|c|c|c|c|c|c|c|}
\hline Variables & Maize & Soybean & Groundnut & Rice & Cereals & Legumes \\
\hline \multirow[t]{2}{*}{ Age } & -0.014 & 0.015 & 0.004 & -0.005 & -0.020 & 0.019 \\
\hline & $(0.017)$ & $(0.012)$ & $(0.010)$ & $(0.008)$ & $(0.019)$ & $(0.016)$ \\
\hline \multirow[t]{2}{*}{$\operatorname{Sex}(1=$ male $)$} & 0.187 & 0.337 & -0.169 & -0.008 & 0.179 & 0.169 \\
\hline & $(0.471)$ & $(0.319)$ & $(0.283)$ & $(0.213)$ & $(0.518)$ & $(0.430)$ \\
\hline \multirow[t]{2}{*}{ Years of education } & -0.047 & $0.059 * *$ & 0.016 & 0.010 & -0.037 & $0.076 * *$ \\
\hline & $(0.041)$ & $(0.028)$ & $(0.024)$ & $(0.018)$ & $(0.045)$ & $(0.037)$ \\
\hline \multirow[t]{2}{*}{ Member of FBO } & 0.580 & 0.319 & $0.914 * * *$ & $0.295^{*}$ & $0.875 * *$ & $1.233 * * *$ \\
\hline & $(0.364)$ & $(0.247)$ & $(0.219)$ & $(0.165)$ & $(0.400)$ & $(0.332)$ \\
\hline \multirow[t]{2}{*}{ Years of farming } & $0.041 * *$ & -0.011 & -0.006 & -0.005 & 0.037 & -0.017 \\
\hline & $(0.021)$ & $(0.014)$ & $(0.012)$ & $(0.009)$ & $(0.023)$ & $(0.019)$ \\
\hline \multirow[t]{2}{*}{ Access to input shop } & -0.500 & -0.276 & -0.141 & $-0.490 * *$ & $-0.990 * *$ & -0.417 \\
\hline & $(0.438)$ & $(0.297)$ & $(0.264)$ & $(0.198)$ & $(0.482)$ & $(0.400)$ \\
\hline \multirow[t]{2}{*}{ Distance to input shop } & $-0.024^{*}$ & -0.006 & -0.010 & -0.007 & $-0.031 * *$ & -0.016 \\
\hline & $(0.013)$ & $(0.009)$ & $(0.008)$ & $(0.006)$ & $(0.015)$ & $(0.012)$ \\
\hline \multirow[t]{2}{*}{ Access to credit } & 0.395 & -0.016 & -0.072 & -0.010 & 0.385 & -0.088 \\
\hline & $(0.358)$ & $(0.242)$ & $(0.215)$ & $(0.162)$ & $(0.393)$ & $(0.326)$ \\
\hline \multirow[t]{2}{*}{ Access to grain market } & -0.628 & $0.561 *$ & 0.222 & 0.282 & -0.346 & $0.783^{*}$ \\
\hline & $(0.485)$ & $(0.329)$ & $(0.292)$ & $(0.220)$ & $(0.534)$ & $(0.443)$ \\
\hline \multirow[t]{2}{*}{ Research institution access } & -0.444 & -0.368 & $-0.689 * *$ & 0.079 & -0.365 & $-1.057 * *$ \\
\hline & $(0.539)$ & $(0.365)$ & $(0.324)$ & $(0.244)$ & $(0.592)$ & $(0.491)$ \\
\hline \multirow[t]{2}{*}{ Farm Insured } & $3.902 * * *$ & 0.384 & 0.371 & 0.077 & $3.978 * * *$ & 0.755 \\
\hline & $(1.070)$ & $(0.725)$ & $(0.643)$ & $(0.484)$ & $(1.177)$ & $(0.976)$ \\
\hline \multirow[t]{2}{*}{ Distance to market } & $0.069 * * *$ & 0.005 & $0.048 * * *$ & 0.010 & $0.079 * * *$ & $0.053 * * *$ \\
\hline & $(0.019)$ & $(0.013)$ & $(0.011)$ & $(0.009)$ & $(0.021)$ & $(0.017)$ \\
\hline \multirow[t]{2}{*}{ Number of extension visits } & -0.080 & 0.163 & 0.103 & 0.015 & -0.065 & $0.266^{*}$ \\
\hline & $(0.158)$ & $(0.107)$ & $(0.095)$ & $(0.071)$ & $(0.174)$ & $(0.144)$ \\
\hline \multirow[t]{2}{*}{ Soy planting labour } & $0.092 * * *$ & $0.290 * * *$ & 0.022 & -0.009 & $0.083 * *$ & $0.312 * * *$ \\
\hline & $(0.033)$ & $(0.023)$ & $(0.020)$ & $(0.015)$ & $(0.037)$ & $(0.030)$ \\
\hline \multirow[t]{2}{*}{ Soy harvesting labour } & 0.007 & $-0.075 * *$ & 0.025 & -0.020 & -0.013 & -0.049 \\
\hline & $(0.053)$ & $(0.036)$ & $(0.032)$ & $(0.024)$ & $(0.058)$ & $(0.048)$ \\
\hline \multirow[t]{2}{*}{ Maize planting labour } & -0.006 & $-0.062 *$ & -0.029 & $-0.043 *$ & -0.049 & $-0.090 * *$ \\
\hline & $(0.050)$ & $(0.034)$ & $(0.030)$ & $(0.023)$ & $(0.055)$ & $(0.046)$ \\
\hline \multirow[t]{2}{*}{ Maize harvesting labour } & 0.037 & -0.024 & 0.042 & $0.045 *$ & 0.081 & 0.019 \\
\hline & $(0.056)$ & $(0.038)$ & $(0.033)$ & $(0.025)$ & $(0.061)$ & $(0.051)$ \\
\hline \multirow[t]{2}{*}{ Soybean price } & $-1.964 * * *$ & -0.603 & 0.211 & -0.228 & $-2.192 * * *$ & -0.391 \\
\hline & $(0.595)$ & $(0.403)$ & $(0.358)$ & $(0.269)$ & $(0.654)$ & $(0.543)$ \\
\hline \multirow[t]{2}{*}{ Maize weeding labour } & $0.245 * * *$ & 0.045 & -0.017 & -0.039 & $0.206^{* *}$ & 0.028 \\
\hline & $(0.090)$ & $(0.061)$ & $(0.054)$ & $(0.041)$ & $(0.099)$ & $(0.082)$ \\
\hline Soy weeding labour & -0.083 & $-0.137 * *$ & 0.082 & -0.007 & -0.090 & -0.055 \\
\hline & $(0.087)$ & $(0.059)$ & $(0.052)$ & $(0.039)$ & $(0.095)$ & $(0.079)$ \\
\hline Inorganic fertilizer (maize) & $1.022 * * *$ & 0.149 & 0.163 & $0.308 *$ & $1.330 * * *$ & 0.312 \\
\hline & $(0.356)$ & $(0.241)$ & $(0.214)$ & $(0.161)$ & $(0.391)$ & $(0.325)$ \\
\hline Inorganic fertilizer (soybean) & 0.218 & -0.119 & -0.239 & $0.415 * *$ & 0.634 & -0.357 \\
\hline & $(0.425)$ & $(0.288)$ & $(0.255)$ & $(0.192)$ & $(0.467)$ & $(0.387)$ \\
\hline Related to political figure & -0.185 & -0.247 & -0.302 & 0.126 & -0.059 & $-0.549 *$ \\
\hline & $(0.344)$ & $(0.233)$ & $(0.207)$ & $(0.156)$ & $(0.378)$ & $(0.314)$ \\
\hline Affiliated to political party & $1.044 * * *$ & 0.183 & 0.307 & 0.136 & $1.180 * * *$ & 0.489 \\
\hline & $(0.387)$ & $(0.262)$ & $(0.232)$ & $(0.175)$ & $(0.425)$ & $(0.353)$ \\
\hline Education on COVID-19 & $0.670 *$ & 0.286 & -0.112 & 0.094 & $0.764 * *$ & 0.175 \\
\hline & $(0.347)$ & $(0.235)$ & $(0.209)$ & $(0.157)$ & $(0.382)$ & $(0.317)$ \\
\hline 1.DumCovAgric & -0.179 & $0.445 *$ & -0.115 & $0.315 * *$ & 0.136 & 0.329 \\
\hline & $(0.337)$ & $(0.228)$ & $(0.203)$ & $(0.152)$ & $(0.371)$ & $(0.307)$ \\
\hline Observations (R-squared) & $309(0.38)$ & $309(0.53)$ & $309(0.23)$ & $309(0.15)$ & $309(0.38)$ & $309(0.49)$ \\
\hline
\end{tabular}


For the negative external shocks, farmers who are educated about the COVID-19 pandemic are more likely to increase the land allocated to cereals by 0.76 acres relative to framers who are uneducated about the COVID-19 pandemic. Similarly, farmers who consider COVID-19 pandemic to have a negative effect on agricultural production is likely to increase the area under soybean and rice by 0.45 acres and 0.32 acres, respectively. A farmer who is more informed about the impact of the COVID-19 pandemic on agricultural production is more likely to make informed decisions with respect to input and output choices. The measures put in place to contain the spread of the virus disrupted the supply of agro-food products to markets and consumers leading to a shift in the demand for some food relative to the others (Organization for Economic Co-operation and Development, 2020). The markets for cereals are likely to be less affected compared to the perishable markets due to the disruptions in the transportation system as well as agricultural labor markets. In view of this, farmers may respond by allocating more land to cereals relative to other crops. As a short-term mechanism, farmers may be more focused on meeting their household food demand while maximizing their income in the long term by allocating more land to legume production. Reduction in the number of buyers who trade with smallholder farmers due to the restriction imposed by the government of Ghana may be accounting for the disruptions in the land allocation decision between cereals and legumes. Generally, the findings of the study confirm the negative effect of the COVID-19 pandemic on crop choices among rural households in Ghana.

\section{Conclusion}

The novel COVID-19 pandemic is a global health issue that has resulted in huge economic shocks leading to short-term disruptions in the agricultural food systems with possible dire long-term effects. While measures such as social distancing rules, wearing of face masks, travel restrictions, 
quarantines, and lockdowns have been implemented to contain the spread, they are, nevertheless adversely impacting livelihoods, jobs, food and nutrition security and economic activities. Farmers are more likely to benefit from the external shock of COVID-19 by shifting land resources between staples and cash crops depending on the objective of the household. This study extends the literature on land resource allocation by accounting for the effects of the COVID-19 pandemic on land allocation decisions among soybean farmers in the Northern Region of Ghana. The study employs both the probit and seemingly unrelated regression model to identify the factors influencing land allocation decisions and the size of cropland allocated to legumes and cereals. The results revealed that cropland allocation decisions are significantly influenced by age, economic active members within the household, distance to input shop, access to research institute, years of farming experience, access to input shop, relationship with a political figure, perceived negative effects of COVID-19 on agriculture, perceived COVID-19 effects on crop choice, and current cropping practices due to the COVID-19 pandemic.

The size of cropland allocated to legumes and cereals are determined by socio-economic, production, political, external shocks, and institutional factors. More specifically, regarding crop land use, the significant determining factors are years of education, member of farmer association, access to input shop, access to a research institution, farm insurance, distance to output markets, number of extension visits, labor for planting soybean and maize, price of soybean, access to inorganic fertilizer, relation with a political figure and affiliation to a political party, education on COVID-19 pandemic, and perceived negative effects of COVID-19 on agricultural production. 
The findings of our study highlight several important implications that are relevant to smallholder farmers, development practitioners, and policymakers. Differences in commodity prices at different output markets correlate highly with cropland allocation decisions. Improvement in transportation infrastructure and feeder roads connecting farms to major roads are necessary for reducing the transaction cost incurred by smallholder farmers. The transactional cost has implications on crop choice decisions made by farm households and consequently, welfare outcomes. Access to inorganic fertilizer increases the area under cereal cultivation. This finding suggests that the government of Ghana's flagship program on "planting for food and jobs" that provides a $50 \%$ subsidy on the cost of seeds and fertilizers to smallholder farmers must be sustained. Critical to this study is the positive effects of COVID-19 education and the perceived negative effects of COVID-19 on crop land-use decisions. Development practitioners must intensify farmer education on the disruptive effects of the COVID-19 pandemic on agricultural production and the strategies that can be employed to mitigate the negative impact. Understanding local farmer perceptions of the disruptive effects of the COVID-19 pandemic on agriculture will be critical to guide future adaption strategies, campaigns, and possible mitigation efforts. The provision of accurate and timely information on the disruptive effects of the COVID-19 pandemic would enable farmers to determine the "best" possible cropland allocation decision.

\section{References}

Adjimoti, G. O. (2018). Analysis of cropland allocation in rural areas Benin: A fractional multinomial approach. Cogent Food \& Agriculture, 4(1), 1488339.

Afridi, F., Dhillon, A., \& Roy, S. (2020). How has Covid-19 Crisis Affected the Urban Poor? Findings from a Phone Survey. Ideas for India.https://www.ideasforindia.in/topics/povertyinequality/how-has-covid-19-crisis-affected-the-urban-poor-findings-from-a-phone-survey.html (Accessed 15th July, 2020) 
Arouri, M., Nguyen, C., \& Youssef, A. B. (2015). Natural disasters, household welfare, and resilience: evidence from rural Vietnam. World development, 70, 59-77.

Bationo, A., Waswa, B., Okeyo, J.M., Maina, F., Kihara, J., \& Mokwunye, U. (eds.). (2011). Fighting poverty in sub-Saharan Africa: The multiple roles of legumes in integrated soil fertility management. Dordrecht: Springer.

Bezner Kerr, R. B., Snapp, S., Chirwa, M., Shumba, L., \& Msachi, R. (2007). Participatory research on legume diversification with Malawian smallholder farers for improved nutrition and soil fertility. Experimental Agriculture, 43(04), 437-453.

Birthal, P. S., Roy, D., \& Negi, D. S. (2015). Assessing the impact of crop diversification on farm poverty in India. World Development, 72, 70-92.

Blaug, M., \& Mark, B. (1992). The methodology of economics: Or, how economists explain. Cambridge University Press.

Chivenge, P., Mabhaudhi, T., Modi, A. T., \& Mafongoya, P. (2015). The potential role of neglected and underutilized crop species as future crops under water scare conditions in sub-Saharan Africa. International Journal of Environmental Research and Public Health, 12, 5685-5711.

Chibwana, C., Fisher, M., \& Shively, G. (2012). Cropland allocation effects of agricultural input subsidies in Malawi. World Development, 40(1), 124-133.

Dedeurwaerdere, T., \& Hannachi, M. (2019). Socio-economic drivers of coexistence of landraces and modern crop varieties in agro-biodiversity rich Yunnan rice fields. Ecological economics, 159, 177-188.

Elbehri, A., J. Kaminski, S. Koroma, M. Iafrate, and M. Benali (2013), West Africa food systems: An overview of trends and indicators of demand, supply, and competitiveness of staple food value chains, In: Rebuilding West Africa’s Food Potential, A. Elbehri (ed.), FAO/IFAD.

Eldukhery, I., Elamin, N. H., Kherallah, M., \& Abur, A. T. (2010). Impact of high food prices on farmers in the near east. FAO: USA.

FAO. (2016). 2016 international year of pulses - Frequently asked questions. Italy: Rome.

Finnis, E. (2006). Why grow cash crops? Subsistence farming and crop commercialization in the Kolli Hills, South India. American Anthropologist, 108(2), 363-369.

Hassen, A., Talore, D. G., Tesfamariam, E. H., Friend, M. A., \& Mpanza, T. D. E. (2017). Potential use of forage-legume intercropping technologies to adapt to climate-change impacts on mixed crop-livestock systems in Africa: A review. Regional Environmental Change, 17(6), 1713-1724. doi:10.1007/ s10113-017-1131-7 
Jack, B. Kelsey. 2013. "Constraints on the adoption of agricultural technologies in developing countries." Literature review, Agricultural Technology Adoption Initiative, J-PAL (MIT) and CEGA (UC Berkeley).

Jayne, T. S., Chamberlin, J., \& Headey, D. D. (2014). Land pressures, the evolution of farming systems, and development strategies in Africa: A synthesis. Food policy, 48, 1-17.

Kokoye, S. E. H., Tovignan, S. D., Yabi, J. A., \& Yegbemey, R. N. (2013). Econometric modeling of farm household land allocation in the municipality of Banikoara in Northern Benin. Land use policy, 34, 72-79.

Kom, Z., Nethengwe, N. S., Mpandeli, N. S., \& Chikoore, H. (2020). Determinants of small-scale farmers' choice and adaptive strategies in response to climatic shocks in Vhembe District, South Africa. GeoJournal, 1-24.

Kruseman, G., Ruben, R., Kuyvenhoven, A., Hengsdijk, H., \& Van Keulen, H. (1996). Analytical framework for disentangling the concept of sustainable land use. Agricultural Systems, 50(2), 191207.

Laborde, D., Martin, W., Swinnen, J., \& Vos, R. (2020). COVID-19 risks to global food security. Science, 369(6503), 500-502.

Manda, J., Alene, A.D., Gardebroek, C., Kassie, M. and Tembo, G., 2016. Adoption and impacts of sustainable agricultural practices on maize yields and incomes: evidence from Rural Zambia. Journal of Agricultural Economics, 67(1),130-153.

Messina, M. J. (1999). Legumes and soybeans: overview of their nutritional profiles and health effects. The American Journal of Clinical Nutrition, 70(3), 439-450.

Mitter, H., Heumesser, C., \& Schmid, E. (2015). Spatial modeling of robust crop production portfolios to assess agricultural vulnerability and adaptation to climate change. Land use policy, 46, 75-90.

Mpepereki, S., Javaheri, F., Davis, P., \& Giller, K. E. (2000). Soyabeans and sustainable agriculture: promiscuous soyabeans in southern Africa. Field crops research, 65(2-3), 137-149.

Msongaleli, B., Tumbo, S., Rwehumbiza, F., \& Kihupi, N. (2015). Determinants of farm-level decisions regarding cereal crops and varieties in semi-arid central Tanzania. African Journal of Agricultural Research, 10(30), 2968-2978.

Muoni, T., Barnes, A. P., Öborn, I., Watson, C. A., Bergkvist, G., Shiluli, M., \& Duncan, A. J. (2019). Farmer perceptions of legumes and their functions in smallholder farming systems in east Africa. International Journal of Agricultural Sustainability, 17(3), 205-218.

Nilsson, F., 2004. Multifunctionality and Efficient Policy Measures for Landscape Public Goods, SLU Report 123, Uppsala. (http://www-naturvardskedjan.slu.se/documents/publikationer/ nilssonrapport123.pdf ). 
Oczkowski, E., \& Bandara, Y. (2013). Modelling agricultural land use allocation in regional Australia. Australian Journal of Agricultural and Resource Economics, 57(3), 422-440.

Odendo, M., Bationo, A., \& Kimani, S. (2011). Socio-economic contribution of legumes to livelihoods in Sub-Saharan Africa. In A. Bationo, B. Waswa, J. M. Okeyo, F. Maina, J. Kihara \& U. Mokwunye (Eds.), Fighting poverty in Sub-Saharan Africa: The multiple roles of legumes in integrated soil fertility management (pp. 27-46). Dordrecht: Springer Netherlands

OECD Policy Responses to Coronavirus (COVID-19). (2020). COVID-19 and the food and agriculture sector: Issues and policy responses. $\mathrm{https} / / / \mathrm{read} . o e c d-$ ilibrary.org/view/?ref=130 130816-9uut451j4q\&title=Covid-19-and-the-food-and-agriculturesector-Issues-and-policy-responses.

Ojiewo, C., Keatinge, D. J. D. H., Hughes, J., Tenkouano, A., Nair, R., Varshney, R., Siambi, M., Monyo, E., Ganga-Rao, N. V. P. R., \& Silim, S. (2015). The role of vegetables and legumes in assuring food, nutrition, and income security for vulnerable groups in sub-Saharan Africa. World Medical and Health Policy, 7, 187--210.

Olwande, J., Smale, M., Mathenge, M. K., Place, F., \& Mithöfer, D. (2015). Agricultural marketing by smallholders in Kenya: A comparison of maize, kale and dairy. Food Policy, 52, 2232.

Porgo, M., Kuwornu, J. K., Zahonogo, P., Jatoe, J. B. D., \& Egyir, I. S. (2018). Credit constraints and cropland allocation decisions in rural Burkina Faso. Land Use Policy, 70, 666-674.

Quan, J. (1998). Land tenure and sustainable rural livelihoods. Sustainable Rural LivelihoodsWhat Contribution We Make, 167-180.

Nguyen, T. T., Nguyen, L. D., Lippe, R. S., \& Grote, U. (2017). Determinants of farmers' land use decision-making: Comparative evidence from Thailand and Vietnam. World Development, 89, 199-213.

Ragasa, C., \& Mazunda, J. (2018). The impact of agricultural extension services in the context of a heavily subsidized input system: The case of Malawi. World development, 105, 25-47.

Ricker-Gilbert, J., Jayne, T. S., \& Chirwa, E. (2011). Subsidies and crowding out: A double-hurdle model of fertilizer demand in Malawi. American journal of agricultural economics, 93(1), 26-42.

Romstad, E., Vatn, A., Rørstad, P. K., \& Søyland, V. (2000). Multifunctional agriculture. Implications for policy design. Report-Agricultural University of Norway. Department of Economics and Social Sciences. www.nlh.no/ios/Publikasjoner/melding/m-21.pdf

Seck, A. (2017). Fertiliser subsidy and agricultural productivity in Senegal. The World Economy, 40(9), 1989-2006. 
Shelton, H. M., Franzel, S., \& Peters, M. (2015). Adoption of tropical legume technology around the world: Analysis of success. Tropical Grasslands, 39, 198-209

Shikuku, K.M., Winowiecki, L., Twyman, J., Eitzinger, A., Perez, J.G., Mwongera, C. and Läderach, P., 2017. Smallholder farmers' attitudes and determinants of adaptation to climate risks in East Africa. Climate Risk Management, 16, 234-245.

Struik, P. C., \& Kuyper, T. W. (2017). Sustainable intensification in agriculture: the richer shade of green. A review. Agronomy for Sustainable Development, 37(5), 39.

Tamimie, C. A., \& Goldsmith, P. D. (2019). Determinants of soybean adoption and performance in Northern Ghana. African Journal of Agricultural and Resource Economics, 14(4), 292-309.

Thierfelder, C., Cheesman, S., \& Rusinamhodzi, L. (2012). A comparative analysis of conservation agriculture systems: Benefits and challenges of rotations and intercropping in Zimbabwe. Field Crops Research, 137, 237-250.

Van Campenhout, Bjorn, Wilberforce Walukano, Fiona Nattembo, Lydia Nazziwa-Nviiri, and Jaap Blom. 2017. The role of information in agricultural technology adoption: Experimental evidence from rice farmers in Uganda". IFPRI Discussion Paper 1684. Washington, D.C.: International Food Policy Research Institute (IFPRI).

url: http://ebrary.ifpri.org/cdm/singleitem/collection/p15738coll2/id/131516.

Waldman, K.B., Blekking, J.P., Attari, S.Z. and Evans, T.P., 2017. Maize seed choice and perceptions of climate variability among smallholder farmers. Global Environmental Change, 47, 51-63.

Waldman, K. B., Ortega, D. L., Richardson, R. B., Clay, D. C., \& Snapp, S. (2016). Preferences for legume attributes in maizelegume cropping systems in Malawi. Food Security, 8(6), 10871099. doi:10.1007/s12571-016-0616-4 